
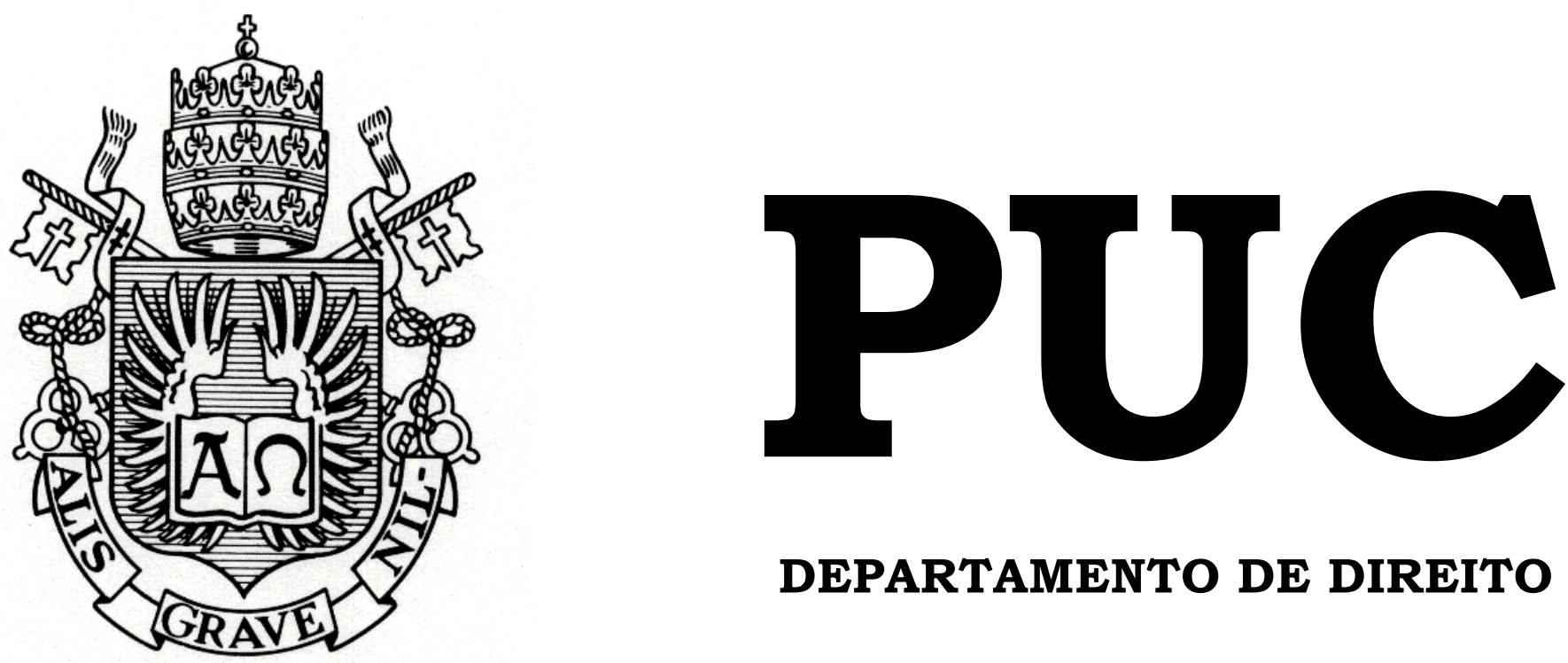

DEPARTAMENTO DE DIREITO

\title{
TEORIA DO DOLO E SUA SUBVERSÃO EM PROL DE UM DIREITO PENAL DA VINGANÇA
}

por

ISADORA CALAZANS EIRA

ORIENTADOR: Breno Melaragno Costa

2014.2

PONTIFÍCIA UNIVERSIDADE CATÓLICA DO RIO DE JANEIRO

RUA MARQUÊS DE SÃO VICENTE, 225 - CEP 22453-900

RIO DE JANEIRO - BRASIL 


\section{TEORIA DO DOLO E SUA SUBVERSÃO EM PROL DE UM DIREITO PENAL DA VINGANÇA}

por

ISADORA CALAZANS EIRA

Monografia apresentada ao Departamento de Direito da Pontificia Universidade Católica do Rio de Janeiro (PUC-Rio) para a obtenção do Título de Bacharel em Direito.

Orientador:

Breno Melaragno Costa 
À minha mãe, por ter sido meu pilar de sustentação Ao meu pai, in memoriam, por ser meu anjo e minha inspiração 


\section{AGRADECIMENTOS}

Agradeço a Deus por ter podido abrir os olhos todos os dias e vivê-los com saúde até aqui.

Agradeço à minha mãe, Maria Luiza Calazans, por estar sempre ao meu lado e ter me ajudado a me tornar a mulher que sou, com os valores que tenho.

Agradeço aos meus familiares e entes queridos, por me ensinarem o significado do amor.

Agradeço às minhas amigas de infância, Raquel Cristina Ribeiro, Carolina Pereira e Tatyane Reis, por serem a prova viva de que amizades podem durar o tempo de uma vida.

Agradeço à minha amiga Débora Calçado, por ter me acompanhado na graduação, ter descoberto comigo a paixão pelo Direito Penal e ter me apresentado à Defensoria Pública do Tribunal do Júri.

Agradeço ao meu amigo Savigny Gonçalves pelo companheirismo e pela troca de conhecimentos ao longo desses cinco anos.

Agradeço ao Pedro Henrique Cordeiro, pela mão sempre estendida em sinal de carinho e atenção.

Agradeço aos meus amigos Giulliana Abranches, Julia Savoia, Narayanna Salgado, Mariana Santos, Caroline Rieken, André Felipe Silva, Maria Eduarda Vianna, Luisa Sertã, Ana Cecília Sabbá e Maria Lúcia Queiroz, por fazerem com que cada conquista tenha o sabor especial de ser compartilhada.

Agradeço ao meu orientador Breno Melaragno, pelo apoio e colaboração no presente trabalho. 


\section{RESUMO}

A presente monografia pretende fazer emergir a problemática da influência midiática e social nos julgamentos criminais cuja questão principal toca a diferença entre dolo eventual e culpa consciente. Disserta sobre a teoria do dolo, o princípio do in dubio pro reo nos crimes dolosos contra a vida e traz à baila dois casos concretos de grande repercussão nos quais a forma de aplicação da teoria se mostra precípua e determinante.

Palavras-chave: Dolo direto - Dolo eventual - Culpa consciente - Culpa inconsciente - Consentimento - In dubio pro reo - Repercussão midiática 


\section{SUMÁRIO}

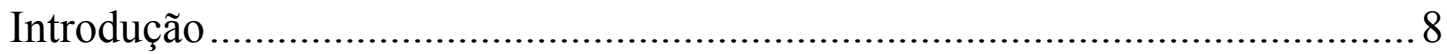

Capítulo 1: Da Teoria do Dolo ........................................................................ 10

1.1 Breve histórico sobre teorias do delito ............................................... 10

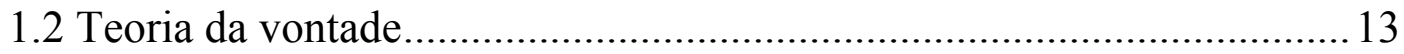

1.3 Teoria da representação ....................................................................... 14

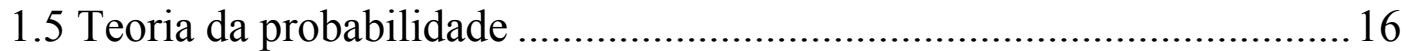

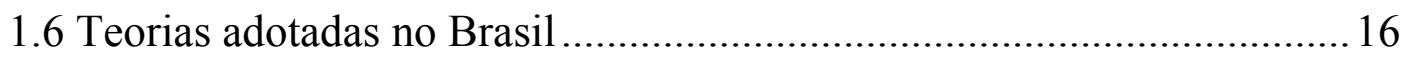

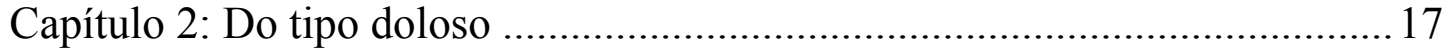

2.1 Dolo direto de primeiro e segundo graus ................................................ 19

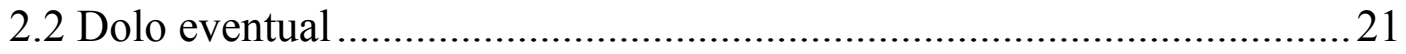

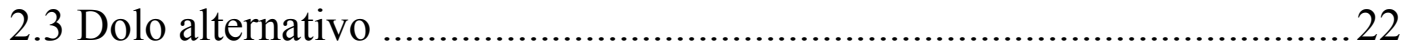

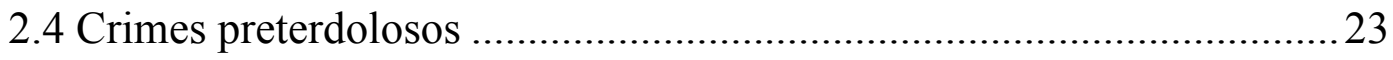

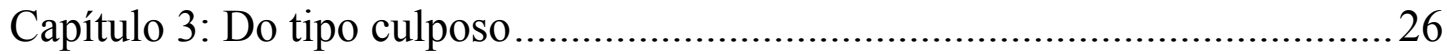

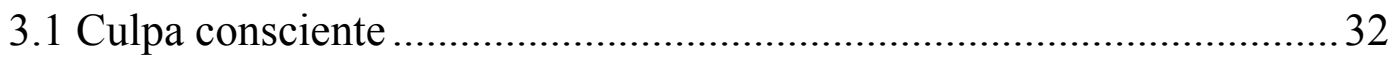

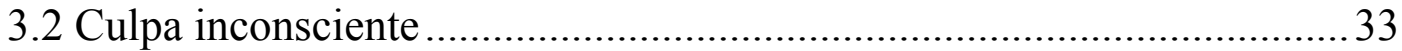

Capítulo 4: Da diferença entre dolo eventual e culpa consciente.......................36

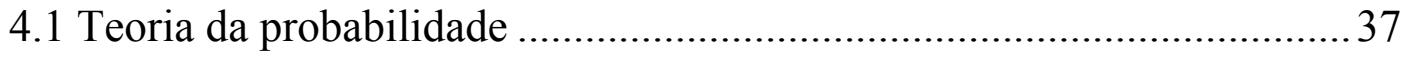

Capítulo 5: Implicações da confusão entre dolo eventual e culpa consciente no

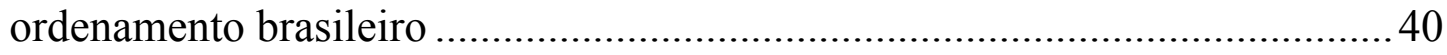

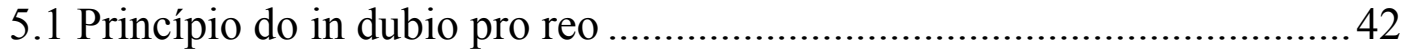

Capítulo 6: Da banalização do dolo eventual em detrimento da culpa consciente nos casos de repercussão midiática....................................................51

6.1 Atropelamento Rafael Mascarenhas .....................................................5

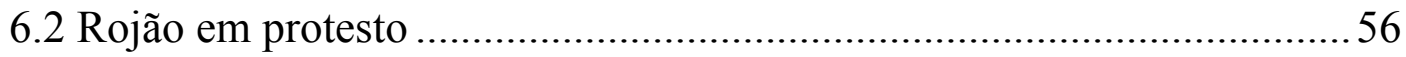




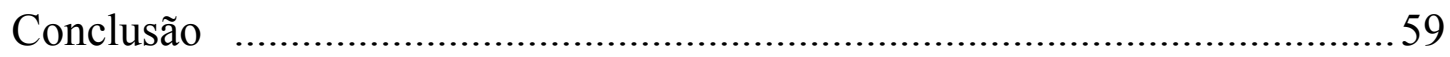

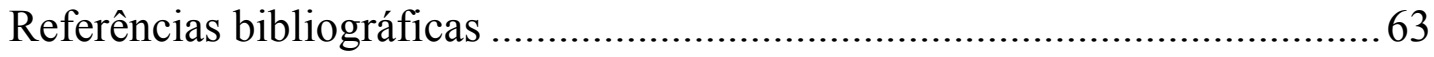




\section{LISTA DE ABREVIAÇÕES E SÍMBOLOS}

Art. - artigo

CPB - Código Penal Brasileiro

CRFB/88 - Constituição da República Federativa do Brasil de 1988

CPP - Código de Processo Penal

CTB - Código de Trânsito Brasileiro

ECA - Estatuto da Criança e do Adolescente

IAB - Instituto dos Advogados Brasileiros

MP - Ministério Público

TJ/RJ - Tribunal de Justiça do Estado do Rio de Janeiro

STF - Supremo Tribunal Federal

$\S$ - parágrafo 


\section{Introdução}

O Direito penal, em apertada síntese, existe para proteger os bens jurídicos mais importantes e o meio pelo qual o faz é imputando àqueles que os lesionam ou põem em risco a mais grave das sanções legais: a pena. Diante disso, o direito penal subjetivo, ou seja, o direito de punir, tem como titular exclusivo o Estado e não é ilimitado, sobretudo porque ao lado do direito estatal de punir existe o direito individual à liberdade. A limitação do direito penal subjetivo se encontra no próprio direito penal objetivo, que é o ordenamento jurídico-penal formado por regras e princípios. ${ }^{1}$ Neste sentido, vale ressaltar a importância do desenvolvimento de teorias e estudos que ao longo do tempo orientam a aplicação da normas.

Uma das teorias que mais provoca discussões na seara do direito penal e que foi escolhida como objeto deste estudo é a teoria do dolo. Isto porque toca pontos sensíveis acerca da subjetividade dos delitos que, por vezes, são extremamente difíceis de serem apreendidos no plano da prova e fazem toda a diferença no que concerne à consequência jurídica do fato em análise. A teoria do dolo será aqui minuciada com os ensinamentos de importantes juristas, tanto na órbita nacional quanto internacional.

Como se verá ao longo do presente trabalho, há uma linha tênue que divide o dolo eventual e a culpa consciente, linha esta muitas vezes rompida sem critério pelo anseio de se satisfazer o desejo de punição. Esse rompimento se dá, sobretudo, quando a titularidade do jus puniendi se vê deturpada pela comoção social e influenciada pela atividade da mídia, problema grave para o qual é preciso abrir os olhos antes que acabemos voltando aos tempos mais primórdios no qual o direito penal era regido pela vingança. E foi a recorrência do referido problema nos dias atuais que motivou a escolha do tema.

Para evidenciar essa problemática de forma mais ilustrativa, trouxemos

\footnotetext{
${ }^{1}$ JESUS, Damásio de. Direito penal: volume 1: parte geral. 32ª ed. São Paulo: Saraiva, 2011, p. 49
} 
à análise dois casos concretos recentes e de grande repercussão na imprensa, quais sejam: o atropelamento do filho da atriz global Cissa Guimarães e a morte de um cinegrafista causada pelo acendimento de um rojão em um protesto. Ambos estão em tramitação e têm como debate central a existência ou não de dolo eventual, debate este acompanhado com afinco pela população através da mídia.

Não se pretende aqui exaurir todas as questões que tangem a teoria do dolo, tampouco trazer a solução para o problema da sua relativização, mas tão somente fazer refletir e demonstrar o quão importante é que se dê a relevância merecida a essa questão. 


\section{Capítulo 1: Da Teoria do Dolo}

\subsection{Breve histórico sobre teorias do delito}

A teoria estratificada moderna do delito é a dogmática que busca explicar através de uma cadeia de questionamentos se determinado fato é ou não crime. Essa teoria sofreu diversas alterações ao longo do tempo e passeou principalmente por três conceitos de delito.

O primeiro deles foi o conceito clássico de Liszt, dominante nos finais do século XIX, que entendia o crime como uma ação, antijurídica, culpável e punível. Este conceito teve como base o positivismo científico e a teoria causal ação, e, por esse motivo, dava ênfase aos elementos objetivos, reservando os poucos aspectos subjetivos apenas à culpabilidade. Caracterizava-se por ter estrutura objetiva-subjetiva, na qual deveriam ser analisadas em separado a ligação física e a ligação psicológica entre o fato e o agente. Roxin explica que o conceito clássico compreendia o injusto penal como a parte externa do delito e a culpabilidade como a parte interna. ${ }^{2}$ Welzel fez duras críticas a este conceito por reservar o dolo à culpabilidade e vê-lo somente como um reflexo da ação na psique do agente, quando na verdade ele não seria um reflexo, mas um fator anterior que determina a ação. ${ }^{3}$ Com a contribuição do pensamento de Beling, acresceu-se ao conceito a tipicidade, e a punibilidade foi afastada como elementar constitutiva do crime, sendo mantida apenas por alguns doutrinadores. ${ }^{4}$

A ação, pela teoria causalista, era basicamente naturalística, ou

\footnotetext{
${ }^{2}$ ROXIN, Claus. Derecho penal: parte general, tomo I: fundamentos, la estructura de la teoria del delito. Trad por PEÑA, Diego-Manuel Luzón; CONLLEDO, Miguel Díaz y García; e ROMESAL, Javier de Vicente. $1^{\text {a }}$ ed. Madrid: Civitas, 1997, p. 198

${ }^{3}$ WELZEL, Hans. Derecho Penal: parte general. Trad. por BALESTRA Carlos Fontán. Buenos Aires: Roque Depalma Editor, 1956, p. 45

${ }^{4}$ ZAFFARONI, Eugenio Raúl; e PIERANGELI, José Henrique. Manual de Direito Penal Brasileiro:

Vol 1 - Parte Geral. $9^{\text {a }}$ ed. Rev. E atual. São Paulo: Revista dos Tribunais, 2011, p. 347 e sgts.
} 
seja, uma ação humana capaz de produzir um resultado através de um nexo de causalidade. A tipicidade era o enquadramento da conduta ao previsto em lei, ou seja, a proibição legal. A antijuridicidade era a valoração negativa da ação, também limitada a uma perspectiva objetiva, onde se analisava a existência de alguma permissão à prática da conduta. A culpabilidade trazia o composto subjetivo que, entretanto, balizava-se somente na existência ou não de um liame psicológico entre o agente e o fato, que poderia ser o dolo ou a culpa. ${ }^{5}$

Em meio ao desenvolvimento da teoria neokantiana no campo filosófico, surgiu o segundo conceito, neoclássico, que provocou profundas mudanças nos componentes do delito, sobretudo porque passou a contemplar elementos subjetivos do tipo. Chegou-se à conclusão de que a culpabilidade era em verdade uma reprovação ${ }^{6}$ (ainda contendo o dolo e a culpa), que para ser examinada não poderia deixar de lado questões objetivas, da mesma forma que era inegável a porção subjetiva da tipicidade. Nas palavras de Roxin:

El concepto de delito denominado hoy mayoritariamente 'neoclásico', que era dominante hacia 1930 y que encontró su mejor expresión en el manual de Mezger (n. 14), pudo certamente mantener en principio la separación entre injusto objetivo y culpabilidad subjetiva y afirmar el dolo como forma de culpabilidad, pero tuvo que reconcer ciertas excepciones y buscar por ello otra explicación distinta para diferenciar injusto y culpabilidad (...) el entendimiento de la culpabilidad como 'reprochabilidad' es lo que caracteriza al denominado concepto normativo de culpabilidad...

Foi, no entanto, por meio do conceito finalístico de Hans Welzel que o abismo entre elementos objetivos e subjetivos teve fim. Alguns destes, como o dolo e a culpa, saíram do campo da culpabilidade para abrigarem-se na ação típica e integrarem o injusto penal. Isto se deu, sobretudo, porque entendeu-se que não era possível conceber uma conduta sem vontade e não

\footnotetext{
${ }^{5}$ BITTENCOURT, Cezar Roberto. Tratado de Direito Penal: parte geral. 16 a ed. São Paulo: Saraiva, 2011, p. 246 e sgts.

${ }^{6}$ ZAFFARONI, Eugenio Raúl; e PIERANGELI, José Henrique. Op. Cit, p. 349

7 ROXIN, Claus. Op. Cit, p. 199.
} 
seria razoável verificar se a conduta ia de encontro à lei antes de se pensar sobre sua finalidade e voluntariedade. Esta, portanto, não poderia estar localizada na culpabilidade. Welzel ensina: "La finalidade es um actuar dirigido concientemente desde el objetivo, mientras que la pura causalidade no está dirigida desde el objetivo, sino que es la resultante de los componentes causales circunstancialmente concorrentes". Segundo o autor, o resultado de uma ação existe em decorrência da causalidade, no entanto, esse resultado é dirigido pelo agente de acordo com aquilo que objetiva ao praticar a conduta. Em suas palavras, a vontade é o fator de direção que determina o acontecimento causal externo, sem a qual seria um "proceso causal ciego". O eminente pensador ressalta, ainda, que uma ação só é finalista no que tange aos resultados objetivados pela vontade. Com relação aos demais resultados não queridos, a relação seria puramente causal. ${ }^{8}$ Fato é que toda ação humana é finalística, objetiva uma finalidade determinada, finalidade esta que pode ou não ser penalmente relevante, tendo em vista as proibições promovidas pelo direito.

A teoria finalista da ação encontrou alguns obstáculos à sua plena aceitação, sobretudo no que tange aos delitos culposos e omissivos. Entretanto, sua primordial consequência para a teoria do delito, qual seja o enquadramento do dolo na tipicidade, foi abraçada em uma síntese com o conceito neoclássico. ${ }^{9}$ Isto porque havia outras justificativas que não somente a teoria da ação para que o dolo fosse parte do tipo, entre elas a existência de elementos subjetivos do tipo que pressupõem a existência do dolo, e a questão do crime tentado - a tentativa ganha relevância a partir do momento em que se verifica a intenção do agente, já que o resultado por ele pretendido não foi alcançado, não houve efetiva lesão ao bem jurídico tutelado. Assim, se o dolo fizesse parte da culpabilidade, não haveria conduta típica na tentativa.

\footnotetext{
${ }^{8}$ WELZEL, Hans. Op.Cit, p. 39

${ }^{9}$ ROXIN. Claus. Op. Cit, p. 202.
} 
Ademais, ela somente se distingue do crime consumado pela ausência de resultado, razão pela qual não haveria motivo para o dolo fazer parte do tipo na tentativa e da culpabilidade quando da consumação. ${ }^{10}$

Outras teorias foram também desenvolvidas, como a teoria social da ação e a teoria funcionalista, que por hora deixaremos de lado.

No Brasil, pode-se dizer que foi adotado o conceito finalista, embora alguns doutrinadores se posicionem no sentido de que a culpabilidade não é parte integrante do conceito formal de crime, mas uma condição à aplicação da pena. ${ }^{11}$

\subsection{Teoria da vontade}

O tipo penal subdivide-se em tipo penal objetivo e subjetivo. $\mathrm{O}$ primeiro liga-se ao aspecto externo do delito, à descrição da conduta a ser incriminada. O segundo liga-se ao aspecto psicológico do agente, à sua vontade de realizar a conduta e atingir o resultado, ao que se denomina dolo. "Incumbe ao tipo subjetivo (dolo) atribuir sentido à conduta típica." 12

No dizer de Patricia Laurenzo Copello:

o dolo como pressuposto do delito, aparece pela primeira vez no Direito romano, onde foi concebido com perfis muito nítidos e definidos, identificando-o com a intenção ou, melhor ainda, com a 'má intenção' ou malícia na realização do fato ilícito (...) a 'intenção imoral dirigida a um fim antijurídico' - o 'dolus malus'. ${ }^{13}$

O dolo se faz presente justamente quando o agente quer o resultado ou assume o risco de produzi-lo, conforme se depreende do art 18, inciso I, do

\footnotetext{
${ }^{10}$ Ibidem, p. 308.

11 JESUS, Damásio de. Op. Cit, p. 197

12 PRADO, Luiz Regis. Curso de direito penal brasileiro: parte geral: arts. $1^{\mathrm{o}}$ a $120.8^{\mathrm{a}}$ ed. Rev., atual. e ampl. São Paulo: Revista dos Tribunais, 2008, p. 316.

${ }^{13}$ COPELLO, Patricia Laurenzo. Apud. GRECO, Rogério. Curso de Direito Penal. 13 ${ }^{\text {a }}$ ed. Rio de Janeiro: Impetus, 2011, p.183.
} 
Código Penal Brasileiro atual, de onde se conclui que há dois tipos principais de dolo: o direto e o indireto ou eventual.

A primeira teoria desenvolvida sobre o dolo foi a teoria da vontade, defendida por Carrara, segundo a qual o dolo seria a vontade de realizar determinada ação geradora de um resultado. Apesar de focar no elemento "vontade", a referida teoria não ignorava a necessidade de um conhecimento do agente acerca das circunstâncias nas quais pratica sua conduta.

\subsection{Teoria da representação}

A teoria da representação, defendida por Liszt e Frank, considerava como dolo o conhecimento das circunstâncias do fato ou a previsão do resultado da ação. Algo como o que Luiz Regis Prado explica denominando teoria monista:

Dá-se então, primazia absoluta ao conhecimento, em detrimento da vontade, na formação do dolo, sob a alegação de que, por exemplo, o primeiro envolve necessariamente a segunda. Então, seria suficiente para a formação do dolo, no delito de resultado, que o agente tivesse atuado com a consciência do perigo de sua produção e, no delito de atividade, que ele conhecesse os elementos integrantes do tipo penal. ${ }^{14}$

O problema dessa teoria se deu com relação ao dolo eventual, segundo lição de Rogério Greco:

Para a teoria da representação, podemos falar em dolo toda vez que o agente tiver tão somente a previsão do resultado como possível e, ainda assim, decidir pela continuidade de sua conduta. Para os adeptos dessa teoria, não se deve perquirir se o agente havia assumido o risco de produzir o resultado, ou se, mesmo o prevendo como possível, acreditava sinceramente na sua não-ocorrência. ${ }^{15}$

\footnotetext{
${ }^{14}$ PRADO, Luiz Regis. Op. Cit, p. 321.

${ }^{15}$ GRECO, Rogério. Op. Cit, p. 186.
} 
Em razão disso, os próprios defensores da teoria da representação acabaram por ceder à teoria da vontade, entendendo que o consentimento do agente com relação ao resultado seria necessário. ${ }^{16}$

\subsection{Teoria do consentimento ou assentimento}

Os dissentimentos das teorias da vontade e da representação culminaram em uma concepção dualista de dolo, pois que chegou-se à conclusão de que o dolo existe quando o agente prevê o resultado $e$ o quer. "Dolo é, ao mesmo tempo, representação e vontade". "A previsão sem vontade é vazia, e a vontade sem previsão é cega". ${ }^{18}$

Ressalta Cezar Roberto Bitencourt que "para a teoria do consentimento, também é dolo a vontade que, embora não dirigida diretamente ao resultado previsto como provável ou possível, consente na sua ocorrência (...) consentir na ocorrência do resultado é uma forma de querê-lo". ${ }^{19}$ Já Julio Fabbrini Mirabete e Renato N. Fabbrini entendem que o consentimento não é um querer e que a teoria do assentimento na verdade determina que "faz parte do dolo a previsão do resultado a que o agente adere, não sendo necessário que ele o queira. Para a teoria em apreço, portanto, existe dolo simplesmente quando o agente consente em causar o resultado." 20

Essa parcela cognitiva do dolo deve abranger todos os elementos descritivos, normativos, circunstanciais, acidentais e de autoria do tipo objetivo no caso concreto. ${ }^{21}$ A consciência sobre o que se faz, entretanto, não pode ser confundida com a consciência sobre a ilicitude do que se faz,

\footnotetext{
${ }^{16}$ BITENCOURT, Cezar Roberto. Op. Cit, p. 316.

${ }^{17}$ Ibid., p. 316.

${ }^{18}$ COSTA JR, Paulo José da. Curso de direito penal. $10^{\mathrm{a}}$ ed. rev. e atual. São Paulo: Saraiva, 2009, p. 98.

${ }^{19}$ BITENCOURT, Cezar Roberto. Op. Cit, p. 317

${ }^{20}$ MIRABETE, Julio Fabbrini \& FABBRINI, Renato N. Manual de direito penal: volume 1: parte geral, arts $1^{\circ}$ a 120 do CP. $27^{\mathrm{a}}$ ed. Rev. E atual. São Paulo: Atlas, 2011. p. 125.

${ }^{21}$ PRADO, Luiza Regis. Op. Cit, p. 320.
} 
conhecimento este que se encontra no campo da culpabilidade, de acordo com a teoria finalista da ação. Assim como a vontade não pode se confundir com a voluntariedade da conduta, haja vista que esta não possui qualquer liame com o resultado da ação, mas tão somente com a sua realização em termos físicos.

\subsection{Teoria da probabilidade}

Pouco defendida, a teoria da probabilidade é aquela segundo a qual para que houvesse dolo seria necessário que o agente, ao prever o resultado, não só o considerasse possível, mas provável de acontecer, independente de sua real vontade. ${ }^{22}$

\subsection{Teorias adotadas no Brasil}

Em geral, entende-se que o Brasil adotou a teoria da vontade e a teoria do consentimento, a primeira com relação ao dolo direto e a segunda, ao dolo eventual. ${ }^{23}$ Entretanto, uma doutrina minoritária afirma a adoção exclusiva da teoria da vontade. ${ }^{24}$

\footnotetext{
${ }^{22}$ BITENCOURT, Cezar Roberto. Op. Cit, p. 317

${ }^{23}$ Ibid., p. 317.

${ }^{24}$ JESUS, Damásio de. Op. Cit, p. 328.
} 


\section{Capítulo 2: Do tipo doloso}

O dolo, como concluído no capítulo anterior, é composto por consciência e vontade. Esta vontade compreende não somente o principal objetivo pretendido pelo agente, mas também os meios necessários e as consequências secundárias atreladas àquele. ${ }^{25}$

De acordo com a ligação existente entre a vontade e cada um dos elementos que constituem o tipo penal, o dolo atinge uma gradação ${ }^{26}$ de dolo direto a dolo indireto (que pode ser alternativo ou eventual). Essa diferença, entretanto, não tem grande importância às vistas do Código Penal, posto que este considera ambos os dolos de maneira igual. ${ }^{27} \mathrm{E}$, tendo o dolo passado a integrar a tipicidade, não é ele considerado uma das referências à dosimetria da pena, embora o bom senso aconselhe os magistrados a punirem mais gravosamente um crime cometido com dolo direto do que eventual.

A despeito dessa indiferença no plano prático, alguns tipos penais, como aqueles que possuem como elementar um especial fim de agir, exigem um dolo específico, que somente pode ser da espécie "direto". No que tange a este assunto, insta salientar que o dolo específico é aquele que ocorre quando "o agente quer um resultado que se encontra fora do fato material" 28 , ou seja, além do simples resultado, mas satisfazendo um fim balizado. Existe uma divergência doutrinaria atinente a esta classificação. Enquanto alguns doutrinadores preferem nomear esse fim especial de dolo específico, outros o encaixam como elemento subjetivo do tipo, que não deixa de precisar estar coberto pelo manto do que seria o dolo genérico para que o tipo subjetivo do injusto se faça completo no caso concreto.

Ademais, há que se falar nos casos excepcionais em que a vontade

\footnotetext{
${ }^{25}$ WELZEL, Hans. Op. Cit, p. 74

${ }^{26}$ BITENCOURT, Cezar Roberto. Op. Cit, p. 318.

${ }^{27}$ Art 18, Código Penal Brasileiro.

${ }^{28}$ JESUS, Damásio de. Op. Cit, p. 334.
} 
diretora da conduta não visa o resultado por ela causado, sendo este decorrente de uma falha do dever de cuidado do agente, os chamados crimes culposos.

Cumpre observar que a vontade de atingir o resultado através da conduta precisa estar dotada de um mínimo de concretude, ou seja, a conduta do agente deve poder efetivamente influenciar na ocorrência do resultado, caso contrário não há dolo. "Tudo o que se localiza assim, fora da possibilidade de influência concreta do agente pode ser desejado ou esperado, mas não significa querer realizar". 29

O dolo, enquanto elemento definidor da ação, existe no momento da realização da conduta, de modo que não há dolo anterior ou posterior. No dizer de Roxin:

El dolo, como base de la realización del plan, ha de concurrir durante la acción ejecutiva, es decir, durante la propia ejecución. No basta um dolus antecedens, es decir, un dolo prévio a la ejecución durante la fase preparatoria (...) pues el dolo en la fase preparatoria no es punible como tal.

Igual que el dolus antecedens, tampoco el dolus subsequens, el dolo subsiguiente o consecutivo, es dolo en sentido jurídicopenal (...) pues sólo puede hablarse de realización del plan cuando el plan existía antes de acometer la acción ejecutiva. ${ }^{30}$

Entretanto, não é necessário que o dolo se mantenha durante toda a fase executória. O mesmo doutrinador usa como exemplo um sujeito que põe uma bomba em um avião. Até que a bomba exploda e mate as pessoas, ainda se está na fase executória e há tempo para o arrependimento do agente. Porém, o autor já concluiu a sua conduta e, mesmo que se arrependa, ocorrendo o resultado deverá ser punido a título de dolo.

$\mathrm{O}$ dolo exige o conhecimento de todas as características do tipo objetivo do injusto no caso concreto e a previsão de que a conduta pode causar o resultado criminoso. Não é necessário que essas características sejam conhecidas exatamente como previstas na lei penal. O conhecimento que aqui

\footnotetext{
${ }^{29}$ TAVARES, Juarez. Espécies de dolo e outros elementos subjetivos do tipo. Revista de Direito Penal. Disponível em <http://ojs.c3sl.ufpr.br/ojs/index.php/direito/article/view/7199/5150>

${ }^{30}$ ROXIN, Claus. Op. Cit, p. 453.
} 
se exige remete ao significado, ao conteúdo do descrito no tipo penal, que uma pessoa leiga seja capaz de constatar. ${ }^{31}$

Damásio de Jesus critica a insuficiência da definição do Código Penal acerca dos crimes dolosos, afirmando que o dolo é muito mais do que querer o resultado ou assumir o risco de produzi-lo. ${ }^{32}$ Qualificadoras, circunstâncias agravantes objetivas, dentre outros apontamentos feitos pelo autor, devem estar também abraçados pelo dolo, além dos crimes de mera conduta que não possuem resultado naturalístico, caso em que o dolo terá foco tão somente na prática da conduta.

\subsection{Dolo direto de primeiro e segundo graus}

O dolo direto existe quando "a vontade do agente é dirigida à realização do fato típico. O objeto do dolo direto é o fim proposto, os meios escolhidos e os efeitos colaterais representados como necessários à realização do fim pretendido." ${ }^{33}$ Importante ressaltar que o dolo direto nesse sentido abrange tudo o que o autor prevê como consequência necessária de sua conduta, independente de efetivamente querê-la ou não. Assim é quando um sujeito pratica uma conduta visando um fim determinado, mas sabe que esta mesma conduta necessariamente desencadeará uma outra consequência típica e, por querer muito praticá-la, o faz. Neste caso, há dolo direto também com relação

a esta outra consequência. A diferença entre o fim inicialmente pretendido e a consequência necessária existirá no chamado "grau" do dolo direto, posto que o primeiro será dolo direto de primeiro grau e a segunda, dolo direto de segundo grau ou dolo de consequências necessárias. Melhor exemplificando, Cezar Bitencourt diz:

\footnotetext{
${ }^{31}$ PRADO, Luiz Regis. Op. Cit, p. 320.

32 JESUS, Damásio de. Op. Cit, p. 332

${ }^{33}$ TAVARES, Juarez. Op. Cit.
} 
Haverá dolo direto de segundo grau quando o agente, querendo matar alguém, coloca uma bomba em um táxi, que explode, matando todos (motorista e passageiros). Inegavelmente, a morte de todos foi querida pelo agente, como consequência necessária do meio escolhido. Em relação à vítima visada o dolo direto foi de primeiro grau; em relação às demais vítimas o dolo direto foi de segundo grau. $^{34}$

Ressalta-se que, quando o sujeito deseja alcançar diretamente o resultado previsto no tipo penal através de sua conduta, não é necessário que o atingimento deste resultado seja certo, basta que seja possível. É o caso do sujeito que, querendo matar, atira à longa distância, sem ter certeza se conseguirá acertar o alvo pretendido. A certeza somente é exigida no que concerne às consequências secundárias. ${ }^{35}$

Imperioso reconhecer que o elemento volitivo com relação à consequência necessária é obviamente menos intenso que com relação ao fim inicialmente pretendido. Entretanto, em ambos os casos é suficiente para dizer que houve um "querer" por parte do agente, de modo que os dois graus do dolo direto encontram-se previstos na primeira parte do art 18, inciso I, do Código Penal, qual seja "quando o agente quis o resultado".

Claus Roxin destaca que no dolo direto o resultado típico não precisa ser o fim último ou único almejado pelo agente, podendo ele servir para a realização de outros fins posteriores, como no caso de alguém que subtrai um bem alheio por querer assim combater o capitalismo. ${ }^{36}$ Entretanto, alguns delitos teriam a intenção como verdadeiro caráter constitutivo e estes somente poderiam ser cometidos com dolo direto de primeiro grau. Um exemplo pelo autor citado é o do preso que, ao fugir da cadeia, sai com a roupa de detento, subtraindo-a do patrimônio do Estado. Neste caso, a subtração da roupa é consequência necessária à conduta da fuga, porém não seria razoável pensar

\footnotetext{
${ }^{34}$ BITENCOURT, Cezar Roberto. Op. Cit, p. 320.

${ }^{35}$ ROXIN, Claus. Op. Cit, p. 418.

${ }^{36}$ Ibid. p. 418
} 
que o preso em algum momento quis essa subtração.

\subsection{Dolo eventual}

No dolo eventual, o agente pratica a sua conduta visando um fim não necessariamente típico, mas o quer com tanta veemência que não se importa com os resultados típicos que sua ação pode trazer. "O agente prevê o resultado como provável ou, ao menos, como possível, mas, apesar de prevêlo, age aceitando o risco de produzi-lo". 37 "Entre desistir da conduta e causar o resultado, prefere que este se produza" ${ }^{38}$ Como bem explica Zaffaroni, o dolo eventual "é a conduta daquele que diz a si mesmo 'que aguente', 'que se incomode', 'se acontecer, azar', 'não me importo'. Observe-se que aqui não há uma aceitação do resultado como tal, e sim sua aceitação como possibilidade, como probabilidade". ${ }^{39}$ Damásio de Jesus, a reverso, entende que na hipótese supramencionada haveria verdadeiro dolo direto:

Se o sujeito mentaliza o evento e pensa 'para mim é indiferente que ocorra, tanto faz,dane-se a vítima, pouco me importa que morra', não é necessário socorrer-se da forma eventual. Se essa atitude subjetiva passa pela mente do sujeito durante a realização da conduta, trata-se de dolo direto, uma vez que a previsão e o acrescido consentimento concreto, claro e atual, não se tratando de simples indiferença ao bem jurídico, equivalem ao querer direto. ${ }^{40}$

Para este autor, o dolo eventual não exige que o agente faça uma reflexão meticulosa sobre a possibilidade do resultado e sua aceitação. Data vênia, filio-me ao primeiro entendimento.

A grande diferença entre o dolo eventual e o dolo direto de segundo grau é que neste caso a consequência típica é necessária ante ao meio escolhido ou ao fim pretendido pelo agente, enquanto que no dolo eventual a

\footnotetext{
${ }^{37}$ BITENCOURT, Cezar Roberto. Op. Cit, p. 321

38 JESUS, Damásio de. Op. Cit, p. 330.

${ }^{39}$ ZAFFARONI, Eugenio Raúl; e PIERANGELI, José Henrique. Op. Cit, p. 434

${ }^{40}$ JESUS, Damásio de. Op. Cit, p. 331
} 
consequência típica é tão somente possível ou, no máximo, provável.

\begin{abstract}
A diferenciação com o dolo direto deve se dar, primeiramente, em que naquele, a associação representativa se fixa na certeza de que as consequências ligar-se-ão necessariamente aos meios ou ao fim, enquanto que neste esta ligação se representa apenas como possível na mente do autor. O caráter de ligação necessária ou somente possível na mente do autor é que marca já, dentro do momento intelectivo, a linha divisória entre as duas espécies de dolo. ${ }^{41}$

Por el dolo directo (de segundo grado) son abarcadas todas las consecuencias que, aunque no las persigue, el sujeto prevé que se producirán con seguridade; y con dolo eventual actúa quien no persigue un resultado y tampoco lo prevé como seguro, sino que sólo prevé que es posible que se produzca, pero para el caso de su producción lo assume en su voluntad. ${ }^{42}$
\end{abstract}

O dolo eventual se perfaz, ainda, quando o agente não tem certeza sobre a existência de alguma circunstância prevista no tipo penal objetivo, mas assume o risco de estar praticando a conduta mesmo que ela exista. O exemplo trazido por Zaffaroni ${ }^{43}$ é o do sujeito que desconfia ter uma doença venérea e, ainda assim, mantém relações sexuais com outra pessoa sem precaução, assumindo o risco de infectá-la. Neste caso, a dúvida paira sobre uma circunstância exigida pelo tipo penal que é estar o agente infectado por doença venérea, haja vista que somente manter relação sexual consensual sem precauções é atípico. O que torna a conduta típica é justamente a circunstância de estar o agente infectado.

Cumpre observar que nem todos os crimes dolosos admitem o dolo eventual. Aqueles que exigem um especial fim de agir, somente podem ser configurados na presença do dolo direto. Isto porque para que a conduta seja típica o agente deve tê-la praticado com uma finalidade determinada.

\title{
2.3 Dolo alternativo
}

\footnotetext{
${ }^{41}$ TAVARES, Juarez. Op. Cit.

${ }^{42}$ ROXIN, Claus. Op. Cit, p. 415.

${ }^{43}$ ZAFFARONI, Eugênio; e PIERANGELI, José Henrique. Op. Cit, p. 434
} 
"No dolo alternativo o agente quer, indiferentemente, um evento ou outro". " 44 "O conteúdo do dolo não é preciso, definido. Neste caso, poderá existir dolo alternativo, em que o agente quer, entre dois ou mais resultados (matar ou ferir, por exemplo), qualquer deles". ${ }^{45}$ Quando o agente se contentar com diferentes resultados, haverá dolo alternativo objetivo; quando com diferentes vítimas, haverá dolo alternativo subjetivo.

Rogério Greco ilustra o dolo alternativo como uma combinação de dolo direto e dolo eventual. Em sua palavras:

O conceito de dolo alternativo é um misto de dolo direto com dolo eventual. Sim, porque quando o agente quer ferir ou matar a vítima seu dolo é dirigido diretamente a uma pessoa determinada; mas, no que diz respeito ao resultado, encontramos também uma 'pitada' de dolo eventual, haja vista que o agente, quando direciona sua conduta a fim de causar lesões ou a morte de outra pessoa, não se importa com a ocorrência de um ou de outro resultado, e se o resultado mais grave vier a acontecer este ser-lhe-á imputado a título de dolo eventual. ${ }^{46}$

O dolo alternativo é pouco tratado pela doutrina atualmente, que, em geral, considera a classificação ultrapassada. Claus Roxin, entretanto, teceu considerações a respeito do tema no que tange à punibilidade. Faz o autor emergir opiniões segundo as quais deveria haver punição com relação a cada um dos tipos alternativos (um tentado e um consumado ou dois tentados) ou que deveria se punir tendo por base o delito mais grave, posicionando-se em apoio à primeira. ${ }^{47}$

\subsection{Crimes preterdolosos}

Trata-se de uma espécie de crime qualificado pelo resultado, que é

\footnotetext{
${ }^{44}$ COSTA JR, Paulo José da. Op. Cit, p. 100

${ }^{45}$ MIRABETE, Julio \& FABBRINI, Renato N. Op. Cit, p. 129.

${ }^{46}$ GRECO, Rogério. Op. Cit, p. 189.

${ }^{47}$ ROXIN, Claus. Op. Cit, p. 456.
} 
aquele penalizado mais gravemente de acordo com a maior lesividade do resultado. O crime preterdoloso configura-se quando um resultado mais danoso ocorre sem a pretensão do agente. "Há uma conduta que é dolosa, por dirigir-se a um fato típico, e que é culposa pela causação de outro resultado que não era objeto do crime fundamental pela inobservância do cuidado objetivo". ${ }^{48}$ Ocorre uma verdadeira combinação de dolo e culpa. Isto porque a conduta se inicia dolosa e termina culposa. No dizer de Cezar Bitencourt, "há dolo no antecedente e culpa no consequente" ${ }^{49}$. O crime doloso acaba por se tornar mais grave dada a ocorrência de outro resultado, pior, não querido pelo agente. Heleno Fragoso cita como exemplo o resultado morte advindo nos crimes de abandono de incapaz, de omissão de socorro, de maus tratos ou de rixa. ${ }^{50}$ Ressalta, ainda, o mencionado autor, que, ao contrario do que pensam alguns doutrinadores, não há que se falar aqui em responsabilidade penal objetiva. Isto porque a lei só prevê uma punição mais severa se o resultado mais grave tiver ocorrido pelo menos a título de culpa. ${ }^{51}$ Atenção para o fato de que se o resultado mais grave puder se enquadrado no dolo do agente, ou seja, se de alguma forma foi querido por ele, não há mais crime preterdoloso e a capitulação do crime é alterada. Entretanto, para alguns crimes, como é o caso do latrocínio (roubo qualificado pelo resultado morte), a sanção cominada é tão severa que a doutrina passou a considerar a possibilidade de enquadrar como latrocínio o fato, mesmo quando o resultado morte não ocorre a título de culpa, mas de dolo. ${ }^{52}$ Teria havido, no caso, um erro do legislador por ter cominado uma sanção única (reclusão de 20 a 30 anos) ao roubo que resulta em morte, não diferenciando se esta morte se deu por dolo, culpa ou preterdolo.

\footnotetext{
${ }^{48}$ MIRABETE, Julio Fabrini \& FABBRINI, Renato N. Op. Cit, p. 139

${ }^{49}$ BITENCOURT, Cezar Roberto. Op. Cit, p. 344

${ }^{50}$ FRAGOSO, Heleno Cláudio. Lições de direito penal: parte geral. $16^{\text {a }}$ ed. rev. por Fernando Fragoso. Rio de Janeiro: Forense, 2004. p. 216

${ }^{51}$ Artigo 19, CP.

${ }^{52}$ BITENCOURT, Cezar Roberto. Código Penal Comentado. $5^{\text {a }}$ ed. atual. São Paulo: Saraiva, 2009. p. 580
} 
Apesar de a doutrina entender que é possível a existência de crime qualificado pelo resultado mesmo quando há dolo no antecedente e também dolo no consequente, a jurisprudência tem se manifestado no sentido de que nestes casos haveria concurso de crimes dolosos. No exemplo de um estupro seguido de morte, se a morte ocorre a título de culpa, aplicar-se-á a agravante; mas se ocorre a título de dolo eventual, haverá verdadeiro concurso de estupro e homicídio. ${ }^{53}$

Cezar Bitencourt ressalta que, a despeito de a nomenclatura crime preterdoloso ser em geral utilizada pela doutrina como sinônimo de crime qualificado pelo resultado, este, em verdade, é aquele no qual o resultado mais grave não contém o resultado pretendido pelo agente. Para facilitar a compreensão da diferença, o doutrinador compara a lesão corporal seguida de morte do aborto seguido de morte da gestante. O primeiro crime seria preterdoloso, pois que é impossível matar alguém sem provocar na vítima uma lesão. Todavia, o segundo crime seria qualificado pelo resultado, posto que para matar alguém não é caminho necessário fazer neste alguém um aborto. ${ }^{54}$

\footnotetext{
${ }^{53}$ NUCCI, Guilherme de Souza. Código Penal Comentado. $11^{\text {a }}$ ed. rev., atual. e ampl. São Paulo: Revista dos Tribunais, 2012. p. 226

${ }^{54}$ BITENCOURT, Cezar Roberto. Tratado de Direito Penal: parte geral, p 344
} 


\section{Capítulo 3: Do tipo culposo}

Como se pode aduzir do primeiro capítulo deste trabalho, o direito penal individualiza condutas proibidas e toda conduta pressupõe uma vontade, vontade esta dirigida a um fim. Nos tipos dolosos, o foco da proibição está justamente no resultado que a conduta almeja alcançar. No caso dos tipos culposos, entretanto, o foco da proibição não está na finalidade da conduta. Isto porque a finalidade da conduta nos tipos culposos, em geral, é um resultado atípico, não proibido pela lei penal. Os tipos culposos, em verdade, focam na forma como a conduta foi realizada, posto que a forma, por não estar munida do dever de cuidado, acaba por culminar na realização de um resultado tipicamente previsto. No dizer de Zaffaroni: "No dolo, o típico é a conduta em razão de sua finalidade, enquanto na culpa, é a conduta em razão do planejamento da causalidade para a obtenção da finalidade proposta". ${ }^{55}$ Cezar Roberto Bitencourt também explica:

O conteúdo estrutural do tipo de injusto culposo é diferente do tipo de injusto doloso: neste, é punida a conduta dirigida a um fim ilícito, enquanto no injusto culposo pune-se a conduta mal dirigida, normalmente destinada a um fim penalmente irrelevante, quase sempre lícito. ${ }^{56}$

A conclusão a que se chega é de que o crime culposo ocorre quando o agente provoca através de sua conduta um resultado que não quis, tampouco assumiu o risco de produzir. Não obstante, o tipo culposo continua sendo ontologicamente finalista, existe uma finalidade na ação e a culpa enquadra-se na tipicidade, tal como o dolo, e não na culpabilidade como já se chegou a defender. "O agente que conduz um veículo e causa, de forma não dolosa, a morte de um pedestre realiza uma ação finalista: conduzir o veículo. O fim da

\footnotetext{
${ }^{55}$ ZAFFARONI, Eugênio; e PIERANGELI, José Henrique. Op. Cit, p. 441-444.

${ }^{56}$ BITENCOURT, Cezar Roberto. Tratado de Direito Penal: parte geral, p. 329.
} 
ação - ir a um lugar determinado - é jurídico-penalmente irrelevante." 57

Cumpre ressaltar a importância da ocorrência do resultado danoso para que seja configurado o crime culposo. Não basta a prática de uma conduta sem cautela. Mirabete chega a dizer que o resultado é o verdadeiro "componente de azar" na conduta imprudente porque sem ele não seria responsabilizado aquele que agiu imprudentemente. ${ }^{58} \mathrm{E}$ é a própria lei, através do artigo 18 , inciso II, do Código Penal, que exige o resultado, ao dizer que há crime culposo quando o agente dá causa a um resultado por imprudência, negligência ou imperícia. Rogério Greco dá relevo a duas exceções: crimes de mera conduta previstos nos artigos 228 e 229 do ECA (Lei 8069/90). ${ }^{59}$

Durante um tempo entendeu-se que a tipicidade objetiva dos crimes culposos se dava por conta da causalidade, pelo fato de a conduta ter gerado o resultado típico, ainda que não fosse pretendido pelo agente. Todavia, esse raciocínio não prospera, visto que não basta a causalidade. Welzel, inclusive, evidencia que a proibição estrita a lesões aos bens jurídicos poderia levar a uma total paralização da vida social. É preciso que haja um desvalor na ação que justifique sua tipificação. Para o mencionado autor,

el desvalor de acción de los tipos culposos consiste en la omisión de una dirección finalist mejor, impuesta por el derecho con miras a evitar lesiones de bienes jurídicos.

(...) El derecho impone, por tanto, a quien actúa, un deber objetivo para un determinado aporte finalista: el deber de observancia de la diligencia necesaria en el intercambio. Solamente acciones que, a consecuencia de la no observancia de este deber objetivo de diligencia, conducen a la lesión de bienes jurídicos, son tipicamente antijurídica, en el sentido de los tipos culposos de delitos. ${ }^{60}$

Em suma, uma conduta pode causar um resultado proibido, mas se não tiver havido infringência ao dever objetivo de cuidado, a conduta não será típica. E mais: ainda que a conduta produza o resultado proibido e haja

\footnotetext{
${ }^{57}$ Ibid, p. 329.

${ }^{58}$ MIRABETE, Julio Fabbrini \& FABBRINI, Renato N. Op. Cit, p. 133

${ }^{59}$ GRECO, Rogério. Op. Cit, p. 199.

${ }^{60}$ WELZEL, Hans. Op. Cit, p. 136
} 
violação ao dever de cautela, se a produção do resultado não se der em razão da violação, tampouco haverá conduta típica. É o que Bitencourt chama de "conexão interna entre desvalor da ação e desvalor do resultado". ${ }^{61}$

Não basta que a conduta seja violadora do dever de cuidado e cause o resultado, mas que, além disto, deve haver uma relação de determinação entre a violação do dever de cuidado e a causação do resultado, isto é, que a violação do dever de cuidado deve ser determinante do resultado.

(...) não basta que o resultado se tenha produzido, mas contrariamente requer-se ainda que tenha sido causado em razão da violação do dever de cuidado. ${ }^{62}$

Roxin também explica:

Si alguien conduce a velocidad excesiva y un transeúnte se le echa encima del coche con tan mala fortuna que no se habría podido evitar el resultado lesivo ni siquiera respetando la velocidad proscrita, la imprudencia no tiene lugar por falta de realización del peligro. ${ }^{63}$

Como visto, para que seja culposamente típica, além de causar perigo ou lesão a um bem jurídico tutelado pelo ordenamento - sem resultado típico não há crime culposo -, a conduta em análise deve ter sido praticada infringindo o dever objetivo de cuidado. "Não há um dever de cuidado geral, mas a cada conduta corresponde um dever de cuidado" ${ }^{64}$, e para se saber qual o dever de cuidado que uma determinada conduta inspirava, é preciso verificar a sua finalidade. $\mathrm{O}$ dever de cuidado que se exige de um motorista que atropela alguém dirigindo um veículo não é o mesmo que se exige de um mecânico que, ao consertar um veículo, o faz disparar e atropelar alguém, ainda que o fato (atropelamento por veículo automotor) seja o mesmo. Dai o porquê de se dizer que os tipos culposos são tipos abertos, que somente se completam quando se conhece o dever de cuidado violado. Há uma doutrina que questiona a compatibilidade dessa abstração com o princípio do "nullum

\footnotetext{
${ }^{61}$ BITENCOURT, Cezar Roberto. Tratado de Direito Penal: parte geral, p. 336

${ }^{62}$ ZAFFARONI, Eugênio; e PIERANGELI, José Henrique. Op. Cit, p. 447.

${ }^{63}$ ROXIN, Claus. Op. Cit, p. 1001.

${ }^{64}$ ZAFFARONI, Eugênio; e PIERANGELI, José Henrique. Op. Cit, p. 443.
} 
crimen sine lege", haja vista que faltaria uma precisão quanto às condutas dos delitos imprudentes, cabendo ao juiz no caso concreto determinar os requisitos do que seria a conduta prudente devida. Porém, majoritariamente, entende-se que os crimes culposos estão vinculados aos tipos dolosos, que cumprem plenamente a exigência da legalidade. Ademais, a menor determinação dos tipos culposos seria compensada por uma ampliação nas possibilidades de exclusão da culpabilidade com base na incapacidade subjetiva do agente de prever o risco criado. ${ }^{65}$

Alguns desses deveres de cuidado são regulamentados pela lei, outros decorrem do que se espera socialmente do homem diante de determinada situação, de acordo com as condições do caso concreto. Entretanto, Zaffaroni salienta que não se pode confundir a regulamentação do dever com a própria tipicidade da conduta $^{66}$, ou seja, infrações administrativas (uma multa, por exemplo) com crimes. Antigamente, o código penal de 1890 previa uma presunção de culpa nos casos em que o agente descumpria uma norma regulamentar. Tratava-se da adoção da responsabilidade penal objetiva, o que se considera abandonado pela legislação pátria atual. ${ }^{67}$

Essencial é observar que o avanço na vida social, sobretudo na área tecnológica, trouxe um aporte enorme de ações que, em sua substância, são arriscadas e perigosas, não bastando isto para configurar a violação ao dever de cuidado. Esta violação somente se faz presente quando o risco gerado é acima do socialmente aceitável, do que já se espera. Exemplos clássicos disso são a direção de veículo automotor e a atividade industrial.

Além disso, ao se analisar se alguém agiu ou não de forma descuidada, deve-se ter em mente que o dever objetivo de cuidado é destinado a todas as pessoas, de modo que cada uma delas age esperando que as outras também ajam cautelosamente, é o que se denomina princípio da confiança. "Assim, por

\footnotetext{
${ }^{65}$ ROXIN, Claus. Op. Cit, p. 1029

${ }^{66}$ ZAFFARONI, Eugênio; e PIERANGELI, José Henrique. Op. Cit, p. 445

${ }^{67}$ JESUS, Damásio de. Op. Cit, p. 343.
} 
exemplo, em um cruzamento de trânsito, a quem trafega pela via principal é lícito supor que o outro motorista, que está na via secundária, aguardará sua passagem..." ${ }^{68}$

A inobservância do dever de cuidado pode se manifestar de 3 formas: imprudência, negligência e imperícia. A imprudência caracteriza-se por ser uma ação descuidada, é um fazer, tem caráter comissivo. A negligência, a reverso, é uma omissão. O sujeito deixa de fazer o que deveria, não toma as precauções devidas. A imperícia liga-se a uma atividade profissional, é o despreparo técnico. Bitencourt, entretanto, diz que a imperícia não se confunde com o erro profissional, que é acidental e pode ocorrer ainda que o agente seja cauteloso. ${ }^{69}$ Essa classificação decorre de previsão expressa do Código Penal. Apesar disso, a doutrina tem se posicionado, em atenção ao pensamento já adotado no direito penal europeu, no sentido de que todos esses tipos de conduta podem ser enquadrados em negligência lato sensu, posto que, por vezes, se confundem, e não deixam de ser, em última análise, uma omissão ao dever objetivo de cuidado.

Nos crimes culposos, há uma maior dificuldade de se separar tipo objetivo e tipo subjetivo, entendendo a doutrina não existir um tipo subjetivo nos crimes culposos, já que a culpa teria natureza normativa.

... como a relevância da ação é aferida através de um juizo comparativo entre a conduta realizada e aquela que era imposta pelo dever objetivo de cuidado, não tem sentido a divisão do tipo penal em objetivo e subjetivo, sendo irrelevante a relação volitiva final para a realidade normativa. ${ }^{70}$

Zaffaroni, apesar de como os demais autores, reconhecer a característica distinta dos tipos culposos em face dos tipos dolosos, entende ser possível pensar o tipo subjetivo nos crimes culposos como vontade e

\footnotetext{
${ }^{68}$ BITENCOURT, Cezar Roberto. Tratado de Direito Penal: parte geral, p. 333

${ }^{69}$ Ibid., p. 338

${ }^{70}$ Ibid., p. 332
} 
conhecimento. Vontade de realizar a conduta de determinada forma e conhecimento potencial sobre o perigo que a conduta gera para os bens juridicamente protegidos (previsibilidade do resultado típico). ${ }^{71}$ Roxin já entende de modo diverso, considerando possível a existência de um tipo subjetivo tão somente nos casos de culpa consciente, onde ele se caracterizaria justamente pela previsão efetiva do resultado e crença de sua não ocorrência. ${ }^{72}$

A previsibilidade importa porque somente se pode ser cauteloso quanto a algo previsível. Imperiosa é a necessidade de se diferenciar dois tipos de previsibilidade: a objetiva, onde se averigua se era possível nas circunstâncias do caso concreto que um homem comum, médio, antevisse que sua conduta podia produzir o resultado danoso; e a subjetiva, que deve ser medida de acordo com as características pessoais e experiência de vida do indivíduo que praticou a conduta, de modo a se verificar se poderia ele ter evitado o resultado, se poderia ter sido diligente. A previsibilidade objetiva participa da tipicidade, enquanto a subjetiva se restringe à culpabilidade. "Assim, a observância do dever genérico de cuidado exclui a tipicidade do fato; a observância do dever pessoal de cuidado exclui a culpabilidade". ${ }^{73}$

A previsibilidade deve remeter ao caso concreto, ou seja, exige-se que seja previsível para o autor que o resultado danoso pode vir a ocorrer através do nexo causal que efetivamente ocorreu. Se o resultado era previsível por meio de um nexo causal, mas adveio de outro que não era previsível, não há que se falar em culpa.

El curso causal previsible debe ser idêntico siempre con el producido realmente. Si este último - el producido realmente - no es previsible, no existe ninguna lesión de diligencia, aun cuando el curso causal realmente producido hubiera podido producirse exatamente lo mismo en lugar del previsible. ${ }^{74}$

\footnotetext{
${ }^{71}$ ZAFFARONI, Eugênio; e PIERANGELI, José Henrique. Op. Cit, p. 448

${ }^{72}$ ROXIN, Claus. Op. Cit, p. 1021

${ }^{73}$ JESUS, Damásio de. Op. Cit, p. 339.

${ }^{74}$ WELZEL, Hans. Op. Cit, p. 140.
} 
No Brasil, os tipos culposos são excepcionais, e só existem com expressa previsão legal, conforme disposição do artigo 18, parágrafo único, do Código Penal. "O dolo é a regra; a culpa, a exceção. Sim, porque de acordo com o princípio da intervenção mínima somente as infrações penais mais graves é que merecerão a atenção da lei penal". ${ }^{75}$

\subsection{Culpa consciente}

Também denominada culpa com representação, a culpa consciente se caracteriza por uma efetiva previsão de que o meio empregado para a realização da conduta pode gerar um resultado típico. Atenção para o fato de que a previsão não importa em necessária aceitação do resultado. Pelo contrário, na culpa consciente o agente prevê o resultado, mas acredita que ele não ocorrerá; tem ele a certeza de que terá habilidade suficiente para evitar que o resultado advenha. É o exemplo clássico do motorista que dirige frequentemente acima da velocidade e julga ter aptidão, destreza para faze-lo sem causar um acidente. Ou o exemplo trazido por Damásio de Jesus, do sujeito que pretendendo atirar na caça, prevê que pode acertar seu companheiro, mas confiando em sua pontaria, acredita que não virá a matá-lo, e acaba por atirar e atingi-lo culposamente. ${ }^{76}$

Juarez Tavares destaca que a culpa consciente não se faz presente pelo simples fato de o agente prever o resultado. Mais: é preciso que ele tenha real consciência de que está infringindo o dever de cuidado. Se o agente não tem consciência de estar agindo com descuido, a culpa se descaracteriza e tipificação da conduta se torna impossível, caso contrario haveria verdadeira responsabilização objetiva. ${ }^{77}$

\footnotetext{
${ }^{75}$ GRECO, Rogério. Op. Cit, p. 202.

${ }^{76}$ JESUS, Damásio de. Op. Cit, p. 343.

${ }^{77}$ TAVARES, Juarez. Apud. BITENCOURT, Cezar Roberto. Tratado de direito penal: parte geral. $\mathrm{p}$. 339
} 


\subsection{Culpa inconsciente}

No caso da culpa inconsciente, ou sem representação, o agente não prevê efetivamente que a sua conduta gera um perigo a um bem juridicamente tutelado. Neste caso, tem-se tão somente o conhecimento potencial, ou seja, o agente podia prever e não o fez. Há previsibilidade objetiva, mas não há subjetiva. Não fica caracterizado no caso concreto um liame psicológico qualquer entre o autor e o resultado. ${ }^{78}$ Sendo certo que a imprevisibilidade torna o caso fruto de fortuito ou força maior.

A ausência da efetiva previsão não obsta a concretização do tipo culposo, isto porque ele somente exige que o resultado típico seja previsível, e não previsto.

A tipicidade culposa se satisfaz com um conhecimento 'potencial' do perigo aos bens jurídicos, sem requerer o conhecimento efetivo de tal perigo, isto é, a tipicidade culposa contenta-se com a forma inconsciente, sem que seja necessária a culpa consciente ou com representação. A culpa com representação - o conhecimento efetivo do perigo introduzido pela conduta - é uma forma de culpa e de conhecimento eventual, mas de modo algum necessário para a configuração da tipicidade culposa. ${ }^{79}$

Existe uma doutrina minoritária que nega o caráter culpável, e consequentemente punível, de uma conduta com culpa inconsciente. Isto porque segundo ela, não se poderia cobrar alguém por ter agido de maneira errada quando este sequer tinha consciência de que poderia agir de outra forma. O problema deste entendimento é que não enxergar as consequências danosas em uma situação de perigo já configura uma imprudência. ${ }^{80}$

Cumpre ressaltar que não existem graus de culpa. Basta que seja configurada a violação do dever de cuidado, independente de ser esta violação

\footnotetext{
${ }^{78}$ BITENCOURT, Cezar Roberto. Tratado de direito penal: parte geral. p. 340

${ }^{79}$ ZAFFARONI, Eugênio; e PIERANGELI, José Henrique Op. Cit, p. 451.

${ }^{80}$ ROXIN, Claus. Op. Cit, p. 1020
} 
grave ou leve.$^{81}$ Portanto, a pena em abstrato é a mesma para todos os tipos de culpa. ${ }^{82}$ Entretanto, a jurisprudência vem considerando a representação como um fator a influenciar na aplicação da pena, posto que é mais reprovável o descuido daquele que previu que poderia causar um resultado danoso do que daquele que não previu.

No que tange à previsão do resultado para se estabelecer se no caso concreto houve culpa consciente ou inconsciente, já decidiu há alguns anos a $6^{\text {a }}$ turma do STJ no sentido de que esta análise não deve ser feita de acordo com o que se espera do homem médio, mas em caráter individual.

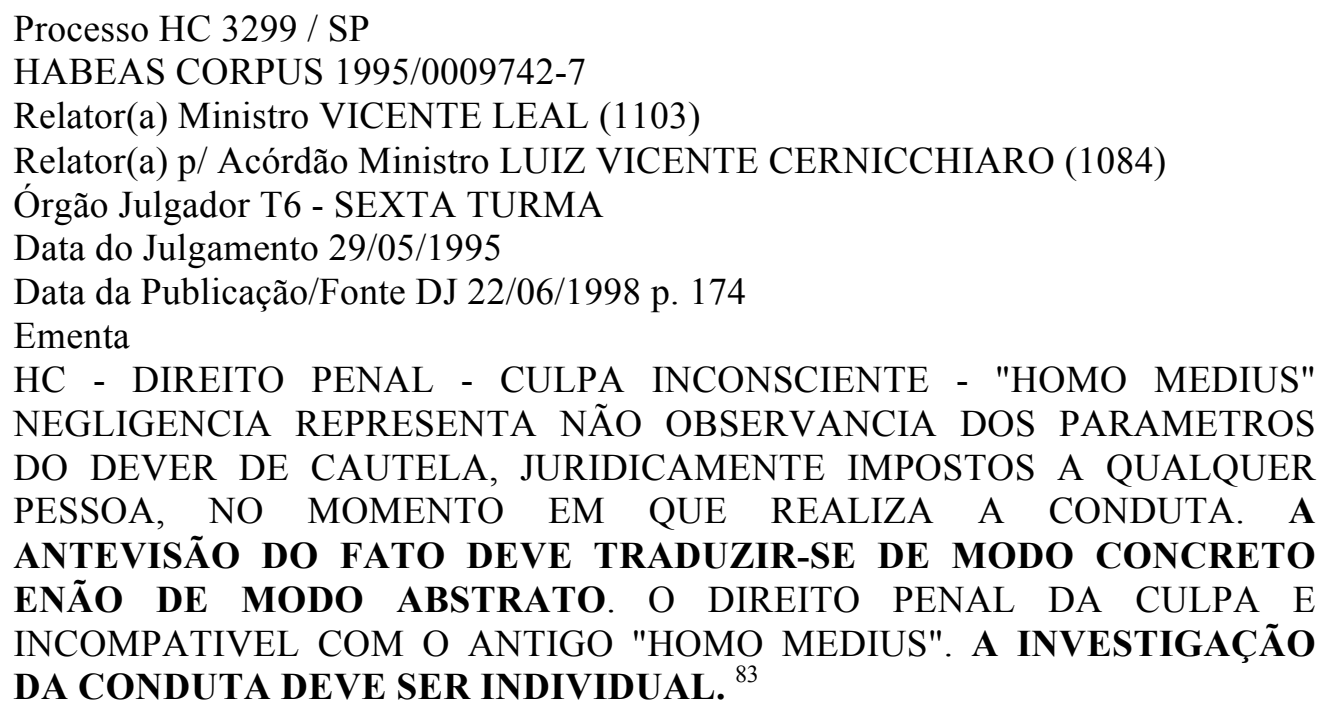

Em julgamento recente do TJ/RJ, ficou evidente também essa questão, posto que por mais óbvia que pareça a situação ensejadora de dano, por mais que o risco pareça saltar aos olhos, isto não necessariamente configura culpa consciente ou dolo eventual. Pode ser que, ainda assim, se considere a existência de culpa inconsciente, sem previsão.

0072238-89.2012.8.19.0002 - RECURSO EM SENTIDO ESTRITO

\footnotetext{
${ }^{81}$ NUCCI, Guilherme de Souza. Op. Cit, p. 218.

82 JESUS, Damásio de. Op. Cit, p. 344.

${ }^{83}$ STJ. HC no 3299/SP, Rel. Min. Vicente Leal, 6 turma, Destrito Federal, 20 mai. 1995.
} 
$1^{\text {a }}$ Ementa

DES. CAIRO ITALO FRANCA DAVID

Julgamento: 03/04/2014

QUINTA CAMARA CRIMINAL

EMENTA

Recurso em Sentido Estrito através do qual a defesa busca a despronúncia do acusado, alegando ausência de dolo na conduta por ele perpetrada, com a desclassificação para a modalidade culposa. 1.Em conformidade com a denúncia, no dia 20 de agosto de 2011, por volta da 07:10 horas, na Avenida Feliciano Sodré, Niterói-RJ, o denunciado teria dado carona às duas vítimas, GABRIELA CORREA DA SILVA e ISADORA BRAGA BEZERRA, em sua moto, e ao ingressar na interseção entre as Avenidas Jansen de Melo e Feliciano Sodré, após se desequilibrar, colidiu lateralmente com um coletivo, causando a queda de GABRIELA CORREA DA SILVA, que veio a falecer, e lesões em ISADORA BRAGA BEZERRA. Foi afirmado que ele teria assumido o risco de causar o resultado morte, tendo agido com dolo eventual, pois não possuía habilitação para conduzir veículos automotores, não usava capacete e concordou em transportar, dando carona a duas pessoas na garupa, frisando-se que as vítimas também estavam sem capacete. Foi ainda afirmado que tudo levava a crer que ele teria desrespeitado o semáforo. E esse somatório de ausência de cuidados importaria no chamado dolo eventual. 2. A despeito de toda a ausência de cautela não se pode falar em dolo indireto, nem mesmo em culpa consciente. $O$ fato é grave. Uma pessoa perdeu a vida e outra ficou lesionada, mas temos que levar em conta não o desvalor do resultado e sim o desvalor da conduta. Não há indicações de que o acusado tenha previsto o resultado e que assim ainda insistiu no seu comportamento. Houve uma colisão com a lateral do coletivo, não sendo razoável supor que o acusado previsse este fato e continuasse a agir colocando em risco a própria vida. Houve, isto sim, um atuar descuidado, imprudente e até irresponsável, mas este somatório de atos negligentes não transforma a culpa, que na hipótese foi inconsciente, em dolo. Houve previsibilidade e ausência de cuidado objetivo, mas não previsão e assunção do resultado. 3. Noto, outrossim, que ele foi pronunciado pela morte de ambas as vítimas, quando uma delas, felizmente, lesionou-se mas sobreviveu e tal questão não foi enfrentada anteriormente. 4. De qualquer sorte, penso que se trata de comportamento culposo, razão pela qual entendo que deva ocorrer a devida desclassificação. 5. Recurso conhecido e provido, considerando-se que ocorreram os crimes descritos nos artigos 302, parágrafo único, inciso I e 303, parágrafo único, ambos da Lei 9.503/97, redistribuindo-se o feito ao juízo competente. ${ }^{84}$

${ }^{84} \mathrm{TJ} /$ RJ. RESE. Processo $\mathrm{n}^{\mathrm{o}}$ 0072238-89.2012.8.19.0002, Rel. Des. Cairo Italo França David, $5^{\mathrm{a}}$ câmara criminal, 03 abr. 2014. 


\section{Capítulo 4: Da diferença entre dolo eventual e culpa consciente}

A questão da distinção entre dolo eventual e culpa consciente ganha relevo à medida em que se baseia estritamente no campo subjetivo do agente, de forma sutil em seu psicológico, o que a torna algo de difícil assimilação probatória.

Como visto nos capítulos anteriores, tanto no dolo eventual, como na culpa consciente, o agente efetivamente prevê a possibilidade de ocorrência do resultado danoso em consequência da conduta por ele tomada. A diferença substancial está no que o agente faz com essa previsão. Isto porque no caso do dolo eventual ele aceita a sua ocorrência, porque dá mais valor à realização do feito pretendido, enquanto na culpa consciente ele acredita piamente que, apesar de possível, o resultado não ocorrerá. "Se estivesse convencido de que o resultado poderia ocorrer, sem dúvida, desistiria da ação" ${ }^{85}$ Sendo válido lembrar que não se pode confundir confiança com esperança. Aquele que não confia ser capaz de evitar o resultado, mas acha que tudo sairá bem por um golpe de sorte, age com dolo eventual. ${ }^{86}$

No dizer de Welzel:

En el dolus eventuais, el autor quiere el hecho incondicionalmente, también para el caso de que se presenten como posibles consecuencias penales secundarias. En la culpa conciente actúa en la esperanza de que evitará la consecuencia criminal representada como posible, o sea, como se la circunstancia representada como posible no existiera. Aquí falta la voluntad incondicional de concreción del hecho, que abarca también las posibles consecuencias típicas secundarias. ${ }^{87}$

Roxin destaca que a delimitação entre o dolo e a culpa, nesse aspecto, é de suma importância porque não representa somente uma diferença no injusto,

\footnotetext{
${ }^{85}$ BITENCOURT, Cezar Roberto. Tratado de Direito Penal: parte geral, p. 342

${ }^{86}$ ROXIN, Claus. Op. Cit, p. 427

${ }^{87}$ WELZEL, Hans. Op. Cit, p. 75
} 
mas sobretudo na culpabilidade, visto que a conduta dolosa, ainda que com caráter eventual, denota uma maior hostilidade ao ordenamento jurídico e, por esse motivo, merece uma maior reprovação. ${ }^{88}$

$\mathrm{O}$ referido autor continua salientando que mesmo nos casos em que o agente é alertado sobre o perigo, não se pode considerar que houve necessariamente dolo eventual.

Cuando p. ej. alguien, a pesar de la advertencia de su acompanhante, adelanta de manera arriesgada y provoca así un acidente, este acidente no estará causado por regla absolutamente general dolosamente, sino sólo por imprudencia consciente, aunque el sujeto (...) conocía las posibles consecuencias e incluso se le había advertido de ellas. La diferencia radica sin embargo en que el conductor, en tal situacióny pese a su consciência del riesgo, confia en poder evitar el resultado mediante su habilidade al volante, pues de lo contrario desistiria de su actuación, porque él mismo sería la primera víctima de su conducta. ${ }^{89}$

Algumas teorias foram criadas na tentativa de melhor diferenciar os dois institutos.

\subsection{Teoria da probabilidade}

Segundo esta teoria, a distinção entre dolo eventual e culpa consciente se faria através de grau de probabilidade da ocorrência do resultado. Probabilidade é mais que possibilidade. Assim, quando a consequência danosa for mais que possível, mas muito provável, haverá dolo. Quando a probabilidade for baixa, haverá culpa.

Welzel criticou esta teoria porque segundo o autor ela dá mais ênfase à capacidade intelectual do agente (de medir o grau de probabilidade do advento do resultado típico) do que à sua vontade, ao dolo em si, apesar de reconhecer que o maior grau de probabilidade pode ser um dos indícios de que o agente

\footnotetext{
${ }^{88}$ ROXIN, Claus. Op. Cit, p. 427

${ }^{89}$ Ibid., p. 425
} 
acreditava no acontecimento do dano. ${ }^{90}$

\subsection{Teoria do consentimento}

Para esta teoria, não basta que o agente compreenda a alta probabilidade de ocorrência do resultado. É preciso que esta probabilidade não obste a sua atuação, ou seja, que o agente dê mais importância à ação pretendida do que à negatividade do resultado consequente.

Cabe mencionar que a teoria do consentimento chegou a ser cogitada em uma interpretação estrita, que considerava existência de dolo eventual apenas quando o agente, ao prever a ocorrência do resultado, a incluía no seu plano, efetivamente acolhendo-o. Esta versão levou ao desenvolvimento de uma outra teoria, a da indiferença, que, por sua vez, entendia haver dolo eventual quando o agente era indiferente quanto à ocorrência do resultado. $\mathrm{O}$ problema é que, a contrário senso, a inexistência de indiferença não importa em necessária inexistência de dolo. ${ }^{91} \mathrm{O}$ agente pode realmente não se contentar com o resultado, mas acatá-lo por desejar muito praticar a conduta.

Frank desenvolveu duas fórmulas que seriam meios de se diagnosticar a existência de dolo eventual ou culpa consciente. A primeira das fórmulas, que dá base à vertente teoria do consentimento hipotético, consiste na indagação sobre se o sujeito deixaria de agir se soubesse com precisão que o resultado iria acontecer. Se mesmo tendo a certeza da produção do resultado o sujeito teria praticado a conduta, pode-se dizer que houve dolo eventual. A segunda fórmula de Frank, que baseia a teoria positiva do consentimento, é aquela segundo a qual age com dolo eventual o sujeito que pensa "de um jeito ou de outro, eu atuarei". ${ }^{92} \mathrm{Ou}$ seja, "o sujeito não leva em conta a possibilidade do

\footnotetext{
${ }^{90}$ WELZEL, Hans. Op. Cit, p. 76

${ }^{91}$ ROXIN, Claus. Op. Cit, p. 432

92 Ibid., p. 439
} 
evento previsto, agindo e assumindo o risco de sua produção". ${ }^{93}$ A teoria do consentimento é a que prevalece na doutrina, entretanto Damásio ressalta que o Código Penal Brasileiro adotou a teoria positiva do consentimento.

Há, ainda, outras teorias desenvolvidas, de menor repercussão, como é o caso das elaboradas por Jakobs, Herzberg e Schroth. Na prática, o que se observa é uma combinação das mais diversas teorias para se apreender no caso concreto a existência ou não do dolo eventual. Leva-se em consideração se o agente acolheu o resultado, se foi indiferente a ele, se o levou a sério, se poderia ter agido para evita-lo, se o considerava muito provável, etc. Roxin ressalta, entretanto, que as tentativas de se suprimir o elemento volitivo no dolo eventual são fadadas ao fracasso; até porque é esse elemento que justifica uma diferente culpabilidade entre o dolo e a culpa. ${ }^{94}$

\footnotetext{
${ }^{93}$ JESUS, Damásio de. Op. Cit, p. 331
}

${ }^{94}$ ROXIN, Claus. Op. Cit, 446 


\section{Capítulo 5: Implicações da confusão entre dolo eventual e culpa consciente no ordenamento brasileiro}

É sabido que o tratamento oferecido pela lei penal aos tipos dolosos e culposos é, em geral, bem discrepante, dada a maior reprovabilidade daquele que lesiona um bem juridicamente tutelado consciente e por vontade frente àquele que o faz por descuido.

Existem diversos crimes que possuem previsão da modalidade culposa no ordenamento jurídico brasileiro e, que portanto, poderiam servir de base para uma confusão entre os institutos do dolo eventual e da culpa consciente na avaliação de um caso concreto. Como o presente trabalho debruçar-se-á sobre dois casos concretos em específico, analisando-os no que tange ao problema supramencionado, o capítulo ora em desenvolvimento se restringe a discorrer sobre o crime nestes casos em evidência, qual seja, o homicídio.

O tipo penal do homicídio está capitulado no art. 121 do CPB e comina uma pena de reclusão de seis a vinte anos àquele que cometer a conduta de matar alguém. A previsão culposa do referido crime vem prevista no $\S 3^{\circ}$ do mesmo artigo, com pena cominada de detenção de um a três anos.

A primeira diferença que se nota é o tipo de pena privativa de liberdade imposta aos condenados. Na modalidade dolosa, a prisão é do tipo reclusão; enquanto na culposa, do tipo detenção. A pena de reclusão é mais severa e utilizada para crimes de maior gravidade. Ela pode ser cumprida em regime inicial fechado, semiaberto ou aberto. Já a pena de detenção jamais se inicia em regime fechado, apenas pode chegar a ele por meio de regressão, o que se pode depreender do art. 33 do CPP. ${ }^{95}$

Outra diferença entre a pena do homicídio doloso e culposo está no mínimo e máximo estabelecidos pelo legislador. Além de, por óbvio, ser pior

\footnotetext{
${ }^{95}$ GRECO, Rogério. Op. Cit, p. 483
} 
ficar preso mais tempo, a pena máxima cominada ao homicídio culposo é de três anos, o que faz com que seu regime inicial possa ser o aberto, se o condenado não for reincidente. $\mathrm{O}$ regime aberto é bem mais brando que os demais e baseia-se, nas palavras da lei, na "autodisciplina e senso de responsabilidade do condenado". Funciona de modo que o condenado pode trabalhar e praticar outras atividades fora do estabelecimento prisional e sem vigilância, retornando a ele no período noturno. ${ }^{96}$ Para o homicídio doloso, a aplicação do regime aberto torna-se bem mais difícil. Isto porque seria atingida apenas com a progressão de regime ou quando o condenado tivesse a pena reduzida por uma causa de diminuição a ponto de não ultrapassar 4 anos.

Outro detalhe diferenciador é quanto à possibilidade de substituição da pena privativa de liberdade por uma restritiva de direitos. Nos crimes culposos, preenchidos os requisitos previstos em lei, a substituição é possível independente do quantum condenatório, enquanto que nos dolosos é preciso que a pena não seja superior a 4 anos e o crime não tenha sido cometido com violência ou grave ameaça (requisitos estes que seriam dificilmente preenchidos em um homicídio doloso). ${ }^{97}$

Além disso, a suspensão condicional do processo somente se aplica quando, presentes os demais requisites, a pena minima é igual ou inferior a 1 ano, o que somente se faz presente no caso do homicídio culposo. ${ }^{98}$

A suspensão condicional da pena tampouco seria possível no homicídio doloso, dada a cominação legal. Isto porque, neste, ainda que o agente fosse condenado ao mínimo legal (6 anos) e tivesse uma diminuição de 1/3 na terceira fase de dosimetria, sua pena não atingiria 2 anos, que é o tempo máximo de condenação passível de suspensão.

Quando o homicídio é culposo, há, ainda, a possibilidade de concessão de perdão judicial ao acusado se o juiz entender que as consequências do

\footnotetext{
${ }^{96}$ Artigo 36 do Código Penal Brasileiro

${ }^{97}$ Artigo 44 do Código Penal Brasileiro

${ }^{98}$ Artigo 98 da Lei 9099/95.
} 
crime o atingiram gravemente de modo a tornar a pena desnecessária, benefício este inexistente na modalidade dolosa. ${ }^{99}$

No que tange à competência, o homicídio doloso é encaminhado ao Tribunal do Júri, conforme artigos $5^{\circ}$, inciso XXXVIII, alínea "d", da CRFB/88, e $74, \S 1^{\circ}$, do CPP, enquanto o homicídio culposo é julgado pelo juiz singular da vara criminal.

Há que se mencionar, ainda, o estigma social, que paira mais fortemente sobre aquele que comete um homicídio doloso do que culposo.

Por fim, insta citar a previsão específica existente no CTB para os homicídios culposos cometidos na direção de veículo automotor. Nestes casos, a pena cominada é de detenção de dois a quatro anos somada à suspensão ou proibição do direito de dirigir, e portanto, mais gravosa. ${ }^{100}$ Além disso, há causas de aumento de pena relacionadas à direção.

\subsection{Princípio do in dubio pro reo}

A constituição, essencialmente garantista, traz em seu bojo uma série de princípios e garantias individuais que devem ser observadas no momento da persecução penal. Com base na obra de Luigi Ferrajoli, o garantismo penal buscou a promoção de decisões judiciais que fossem fruto de profundo conhecimento acerca da matéria sobre a qual recaem. ${ }^{101}$

Um dos princípios mais importantes e basilares é o da presunção de inocência, assegurado no art $5^{\circ}$, inciso LVII, da CRFB/88, segundo o qual ninguém será considerado culpado até o trânsito em julgado de sentença penal condenatória. Este princípio surgiu no Direito Romano e sofreu grande

\footnotetext{
${ }^{99}$ Artigo 121, §5 $5^{\circ}$, do Código Penal Brasileiro

${ }^{100}$ Artigo 302 do Código de Trânsito Brasileiro

${ }^{101}$ OLIVEIRA, Eugênio Pacelli de. Curso de processo penal. $16^{\mathrm{a}}$ ed. atual. de acordo com as Leis $\mathrm{n}$. $12.403,12.432,12.461,12.483$ e 12.529 , todas de 2011, e Lei Complementar n. 140 de 8 de dezembro de 2011. São Paulo: Atlas, 2012. p. 34
} 
repúdio nos tempos da Idade Média, quando a inquisição considerava o réu como objeto de investigação e não como um sujeito de direitos ${ }^{102}$ e a dúvida era suficiente para configurar uma semiprova e ensejar a condenação. Posteriormente, voltou a ser consagrado com o Iluminismo e consta já na Declaração de Direitos do Homem e do Cidadão ("Tout home étant presume innocent jusque'a ce qu'il ait été declare coupable") ${ }^{103}$. Passou novamente por um período de críticas, quando da vigência do fascismo, ${ }^{104}$ mas atualmente, é considerado verdadeiro "pressuposto da condição humana". ${ }^{105}$

A presunção de inocência é um dos maiores indícios de adoção do sistema acusatório de processamento penal pelo Brasil, aquele onde o juiz é um espectador e cabe às partes produzir provas de suas alegações, de modo que cabe ao órgão acusador provar que o réu é culpado, podendo este tão somente negar a acusação. A existência desse princípio se dá, sobretudo, porque é suportável que alguém que cometeu crime saia impune, mas inadmissível que alguém inocente seja injustamente condenado.

A presunção de inocência liga-se também ao princípio da jurisdicionalidade, aquele que exige o exercício da jurisdição para que alguém seja condenado e tenha aplicada uma pena. "Nulla poena, nulla culpa sine iudicio". Isto porque se é necessário que haja um processo para colher provas acerca de um determinado fato para que só então o juiz decida sobre ele, é porque a premissa inicial é de que o acusado é inocente.

Em decorrência da aplicação do princípio da presunção de inocência, chega-se a uma regra de caráter probatório: o in dubio pro reo. Também chamado de princípio do favor rei, estabelece que, havendo dúvida, a

\footnotetext{
${ }^{102}$ TOURINHO FILHO, Fernando da Costa. Processo penal, volume I. $34^{\mathrm{a}}$ ed. rev. e de acordo com a Lei n 12403/2011. São Paulo: Saraiva, 2012. p. 93

${ }^{103}$ Art $9^{\circ}$ da Declaração de Direitos do Homem e do Cidadão de 1789. Disponível em < http://www.legifrance.gouv.fr/Droit-francais/Constitution/Declaration-des-Droits-de-1-Homme-et-duCitoyen-de-1789 >. Acesso em 12 out. 2014.

${ }^{104}$ LOPES JR, Aury. Direito processual penal e sua conformidade constitucional. Volume I, $7^{\mathrm{a}} \mathrm{ed}$. Rio de Janeiro: Lumen Juris, 2011. p 184.

${ }^{105}$ CARVALHO, Amilton B. de. Apud LOPES JR, Aury. Direito processual penal e sua conformidade constitucional. Volume I, $7^{\mathrm{a}}$ ed. Rio de Janeiro: Lumen Juris, 2011. p 184.
} 
interpretação deve ser favorável ao acusado. Este princípio foi incorporado pelo ordenamento brasileiro de forma implícita no art. 386, inciso VII, do $\mathrm{CPP}$, que determina que o juiz absolverá o réu quando não houver prova suficiente para condená-lo. Isto porque se existe alguma dúvida é porque a acusação não desempenhou suficientemente o seu ônus de provar o que alega, devendo, por consequência, prevalecer a presunção de inocência. No dizer de Tourinho, ao traduzir os ensinamentos de Bettiol:

No conflito entre jus puniendi do Estado, por um lado, e o jus libertatis do acusado, por outro lado, a balança deve incliner-se a favor deste ultimo se se quiser assistir ao triunfo da liberdade.

E mais adiante acrescenta o mestre: o favor rei deve constituir um princípio inspirador da interpretação. Isso significa que, nos casos em que não for possível uma interpretação unívoca, mas se conclua pela possibilidade de duas interpretações antagônicas de uma norma legal (antinomia interpretativa), a obrigação é escolher a interpretação mais favorável ao réu. ${ }^{106}$

A despeito de, em geral, se falar do in dubio pro reo para absolvição nos casos em que não há prova de autoria e materialidade, em tradução literal, o princípio determina que a dúvida deve ser favorável ao réu. "Se houver duas interpretações, deve-se optar pela mais benéfica". ${ }^{107}$ Esta dúvida, no plano prático, não necessariamente recai sobre a existência de um crime, mas pode ser sobre algum de seus elementos, como é o caso do tipo subjetivo. Neste sentido, muitos doutrinadores se posicionam entendendo que, havendo dúvida sobre a existência de dolo eventual ou culpa consciente, a interpretação deve ser favorável ao réu, prevalecendo, portanto, a culpa, opinião também defendida pelo presente trabalho.

Zaffaroni já salientara que o liame entre dolo eventual e culpa consciente

no campo processual, configura um problema de prova que, em caso de dúvida

\footnotetext{
${ }^{106}$ TOURINHO FILHO, Fernando da Costa. Op. Cit, p. 96.

${ }^{107}$ CAPEZ, Fernando. Curso de processo penal. 16a ed. São Paulo: Saraiva, 2009. p. 39.
} 
sobre a aceitação ou rejeição da possibilidade de produção do resultado, imporá ao tribunal a consideração da existência de culpa, em razão do benefício da dúvida: in dubio pro reo. ${ }^{108}$

No mesmo sentido, afirma Bitencourt que "persistindo a dúvida entre um e outra, dever-se-á concluir pela solução menos grave, qual seja, pela culpa consciente, embora, equivocadamente, não seja essa a orientação adotada na práxis forenses". ${ }^{109}$

Rogério Greco também endossa:

Se ao final do processo pelo qual o motorista estava sendo processado por um crime doloso (com dolo eventual) houver dúvida com relação a este elemento subjetivo, deverá ser a infração penal desclassificada para aquela de natureza culposa, pois in dubio pro reo, e não, como querem alguns, in dubio pro societate. ${ }^{110}$

Assim como, anos antes, Roxin ressaltara:

Dolo e imprudencia se hallan en una 'relación gradual' de modo que en caso de situación probatoria poco clara se puede condenar por imprudencia conforme al principio 'in dubio pro reo'. ${ }^{111}$

Mais especificamente com relação ao homicídio, a aplicação do in dubio pro reo na interpretação do elemento subjetivo do crime passa por um obstáculo. Isto porque a competência para julgamento do homicídio doloso é do Tribunal do Júri, e o procedimento divide-se em duas fases, sendo a primeira destinada à instrução, que culmina na possível decisão de pronúncia, que leva o caso à apreciação da corte de jurados (segunda fase). Na decisão terminativa da primeira fase do procedimento no Tribunal do Júri, há aplicação de um outro princípio, oposto ao in dubio pro reo, que é o in dubio pro societate. Este princípio ensina que havendo dúvida, o magistrado deve pronunciar o réu, para que a dúvida seja decidida pelos jurados, em

${ }^{108}$ ZAFFARONI, Eugênio; e PIERANGELI, José Henrique. Op. Cit, p. 435

${ }^{109}$ BITENCOURT, Cezar Roberto. Tratado de Direito Penal: parte geral, p. 343

${ }^{110}$ GRECO, Rogério. Op. Cit, p. 209

${ }^{111}$ ROXIN, Claus. Op. Cit, p. 1023 
atendimento ao interesse da sociedade.

A fase da instrução preliminar é, então, reservada para a definição da competência do Tribunal do Júri, com o que se examinará a existência, provável ou possível, de um crime doloso contra a vida. Dizemos provável ou possível porque, nessa fase, o juiz deve emitir apenas juízo de probabilidade, tendo em vista que caberá ao Tribunal do Júri dar a última palavra (a certeza, pois) sobre a existência e sobre a natureza do crime. ${ }^{112}$

Não é raro encontrar na jurisprudência decisões que, seguindo este entendimento, enviam para a corte de sentença do Tribunal do Júri a problemática do dolo eventual e da culpa consciente.

\section{0-62.2011.8.19.0001 - RECURSO EM SENTIDO ESTRITO \\ $1^{\mathrm{a}}$ Ementa. DES. MONICA TOLLEDO DE OLIVEIRA - Julgamento: 03/12/2013 - TERCEIRA CAMARA CRIMINAL}

Recurso em sentido estrito. Pronúncia. Art. $121, \S 2^{\circ}$, II, c/c art. 14, II, todos do Código Penal. Recurso defensivo postulando a desclassificação da imputação para crime não doloso contra vida, remetendo-se, por consequência, os autos a um juízo singular, ou, subsidiariamente, decotar a qualificadora da futilidade. Impossibilidade. In casu, o recorrente restou denunciado porque, em tese, ao ser parado em uma blitz, arrancou com seu veículo, vindo de atingir um fiscal de trânsito do DETRAN. Indícios de autoria e prova de materialidade apoiados pelo Laudo de Exame de Corpo de Delito e depoimentos prestados em juízo, principalmente, pelo relato da vítima, cabendo ao Tribunal do Júri, juiz natural da causa, decidir se o réu agiu com dolo eventual ou culpa consciente, bem como se tal conduta se deu apenas para evitar a apreensão de seu automóvel, vez que sua documentação estava irregular. Desprovimento do recurso. ${ }^{113}$ (grifo nosso)

O Egrégio Supremo Tribunal Federal, recentemente decidiu:

EMENTA RECURSO ORDINÁRIO EM HABEAS CORPUS. HOMICÍDIO NA DIREÇÃO DE VEÍCULO AUTOMOTOR. DOLO EVENTUAL. CULPA CONSCIENTE. PRONÚNCIA. TRIBUNAL DO JÚRI. 1.Admissível, em crimes de homicídio na direção de veículo automotor, o reconhecimento do dolo eventual, a depender das circunstâncias concretas da conduta. Precedentes. 2.Mesmo em crimes de trânsito, definir se os fatos, as provas e as circunstâncias do caso autorizam a condenação do paciente por homicídio doloso ou se, em realidade, trata-se de hipótese de homicídio culposo ou mesmo de inocorrência de crime é questão que cabe ao Conselho de Sentença do Tribunal do Júri. 3.Não cabe na pronúncia

\footnotetext{
112 OLIVEIRA, Eugênio Pacelli. Op. Cit, p. 712

${ }^{113}$ TJ/RJ. RESE. Processo no 0107990-62.2011.8.19.0001, Rel. Des. Monica Tolledo de Oliveira, Rio de Janeiro, 03 dez. 2013.
} 
analisar e valorar profundamente as provas, pena inclusive de influenciar de forma indevida os jurados, de todo suficiente a indicação, fundamentada, da existência de provas da materialidade e autoria de crime de competência do Tribunal do Júri. 4. Recurso ordinário em habeas corpus a que se nega provimento. ${ }^{114}$ (grifo nosso)

Data máxima vênia, para que o magistrado indique fundamentadamente se tratar ou não de um crime de competência do Tribunal do Júri, nos casos de dúvida sobre dolo eventual e culpa consciente, não é imprescindível que analise ele as provas constantes nos autos para delas extrair sua conclusão? E deixar que o Conselho de Sentença decida sobre a existência de dolo eventual ou culpa consciente não é, em última análise, passar para ele o juízo de admissibilidade?

A $6^{\text {a }}$ turma do Superior Tribunal de Justiça já se manifestou no sentido de que a problemática aqui tratada é por demasia profunda e técnica para ser apreciada exclusivamente por pessoas leigas, membros da sociedade. Deste modo, o juiz deve sim debruçar-se sobre esta questão afim de somente enviar para o plenário os casos em que de modo suficiente entender pela competência do Júri.

Processo REsp 1327087 / DF. RECURSO ESPECIAL 2012/0117018-0

Relator(a) Ministro OG FERNANDES (1139)

Órgão Julgador: T6 - SEXTA TURMA

Data do Julgamento 10/09/2013

Data da Publicação/Fonte DJe 11/11/2013

Ementa

RECURSO ESPECIAL. ACIDENTE DE TRÂNSITO. PRONÚNCIA. POR HOMICÍDIO QUALIFICADO. DOLO EVENTUAL. RECURSO EM SENTIDO ESTRITO. DESCLASSIFICAÇÃO PELO TRIBUNAL DE ORIGEM PARA HOMICÍDIO CULPOSO - ARTIGOS 302 E 303 DA LEI N. 9.503/97. ADEQUAÇÃO DO FATO À NORMA JURÍDICA PERTINENTE. POSSIBILIDADE NA FASE DE PRONÚNCIA. ELEMENTO VOLITIVO NÃO CARACTERIZADO. INCOMPETENNCIA DO TRIBUNAL DO JÚRI. ARTS.18, I, E 413 DO CPP. EXEGESE. 1. De ressaltar, desde logo, que a jurisprudência desta Corte firmou-se no sentido de ser possível a revaloração jurídica dos fatos delimitados nas instâncias inferiores, que não se confunde com reexame de provas vedado pelo Enunciado n. 7/STJ. 2. Admissível, portanto, em sede de Recurso Especial, o reexame dos critérios jurídicos utilizados pelo Tribunal de origem na

\footnotetext{
${ }^{114}$ STF. RHC 116950. Rel. Min. Rosa Weber, 1ª turma, Destrito Federal, 03 dez 2013.
} 
apreciação dos fatos considerados incontroversos, à luz dos disposto nos arts. 74, § $1^{\circ}$ e 413, ambos do Código de Processo Penal, e no art. 18, I, do Código Penal, tidos por violados pelo Ministério Público. 3. É certo que, na fase do iudicium accusationis, não se admite longas incursões sobre o mérito da acusação, sob pena de usurpar a competência do Tribunal do Júri. Entretanto, não se pode transferir para a Corte Popular, utilizando-se do brocardo in dubio pro societate, o juízo técnico a respeito da adequação do dolo eventual e da culpa consciente, nas hipóteses de homicídio praticado na direção de veículo automotor, ante as dificuldades óbvias de compreensão desses institutos. 4. Apesar de existir vários conceitos teóricos sob o tema, quando se parte para o campo prático nota-se a extrema dificuldade de distinguir quando o agente assumiu ou não o risco de produzir determinado resultado lesivo, ainda mais quando se tratar de crimes de trânsito, para os quais há legislação própria, inclusive com tipos penais específicos. 5. Nesse contexto, diante da tênue diferença entre dolo eventual e culpa consciente - visto que em ambos o agente prevê a ocorrência do resultado, mas somente no dolo o agente admite a possibilidade de o evento acontecer, cumpre ao Juiz togado verificar se há elementos de convicção suficientes para confirmar a competência do Tribunal do Júri. 6.No caso, observa-se que a Corte de origem para chegar a conclusão de que o réu agiu com culpa consciente, ao contrário do sustentado pelo Parquet, não realizou exame aprofundado do meritum causae, mas sim mera aferição acerca da existência ou não de elementos mínimos para submeter o ora recorrido a julgamento pelo Tribunal do Júri, na forma como autoriza o art. 413 do mencionado diploma. 7. O excesso de velocidade e o número excessivo de passageiros, conquanto possam demonstrar negligência em relação às normas de trânsito, não autorizam a conclusão de que o condutor do veículo, ora recorrido, tenha assumido o risco de causar a morte das vítimas, dentre elas, amigos de longa data e o seu próprio irmão. 8. A embriaguez, como a própria Corte local ressaltou, não foi comprovada, visto que o réu realizou o teste do bafômetro, cujo resultado apresentou índice abaixo do permitido pela lei vigente na época do evento delituoso. 9. Ressalte-se que o acidente ocorreu antes da edição da Lei n. 12.760, cuja norma alterou o Código de Trânsito Brasileiro, especificamente o art. 306, permitindo a utilização de quaisquer meios de prova em direito admitidos para comprovar a embriaguez do motorista. Portanto, na época do fato, uma pessoa somente podia ser considerada embriagada por meio do teste do bafômetro ou exame de sangue. 10 . De outra parte, não houve prova suficiente de que o acidente ocorreu em virtude da participação do recorrido em uma disputa automobilística, pois o depoimento de uma única testemunha, afirmando "achar que o acusado estava fazendo racha, por causa do pista alerta ligado", mostrou-se isolado do contexto probatório dos autos. 11. Diante desse quadro, agiu com acerto a Corte de origem em desclassificar a conduta para a modalidade culposa, visto que não há outros fatores que, somados à alta velocidade empregada $-100 \mathrm{~km} / \mathrm{h}$ - e ao excesso de passageiros, permitam aferir a plausibilidade da acusação pelo delito contra a vida, na modalidade dolosa. 12. Com efeito, a descrição constante na denúncia e os elementos de convicção até aqui colacionados demonstram a ocorrência de uma conduta tipicamente culposa, pois clara e indiscutível a negligência e imprudência do recorrido, mas não aponta para a configuração do dolo eventual, vale dizer, a insensibilidade e a indiferença do acusado pela vida das vítimas que lhe eram tão próximas. 13. Cumpre notar, ainda, que somente quando houver fundada dúvida, ou seja, elementos indiciários conflitantes acerca da existência de dolo, a divergência deve ser dirimida pelo 
Conselho de Sentença, o que não se vislumbra do contexto probatório delineado pela Corte de origem. 14. Recurso especial a que se nega provimento. ${ }^{115}$ (grifo nosso)

É bem verdade que não há um consenso sequer entre as turmas dos tribunais superiores acerca do tema, sendo fácil encontrar decisões diametralmente opostas. Na prática, entretanto, o que se verifica mais comumente é uma tendência dos magistrados de quase sempre pronunciar o réu, mesmo não havendo fortes indícios da existência dolo eventual.

Tratando mais especificamente do princípio do in dubio pro societate, há que se reconhecer que ele se mostra um forte resquício do sistema inquisitivo. Ademais, ainda que muitos argumentem ser ele necessário para evitar violação da competência constitucional do Tribunal do Júri, é imperioso atentar para o fato de que haveria em concreto um conflito entre a preservação de uma competência constitucional e uma garantia individual constitucional de presunção de inocência. Em uma ponderação desses institutos constitucionais, é necessário ter em mente que Júri é formado por pessoas comuns, muito fortemente influenciáveis por discursos externos, sobretudo midiáticos, e que julgam com base na íntima convicção. Desta forma, enviar um réu a julgamento em plenário sem fortes indícios ou provas acerca da existência de dolo eventual é submetê-lo ao risco alto de ser condenado na modalidade dolosa por um crime que cometera culposamente. Sobretudo porque o crime doloso contra a vida é um delito que provoca grande comoção social.

Com efeito, dispõe o artigo 419 do CPP que o juiz remeterá os autos ao órgão competente quando se convencer da existência de crime diverso e não for competente para o julgamento. Tal desclassificação, se omitida indevidamente, importa em graves consequências para a defesa, deslocando o processo ao Júri, cujo julgamento é sabidamente atécnico e, às vezes, até mesmo apaixonado, a depender do local onde ele ocorra. Essas implicações potencializam-se ainda mais no caso sub judice, em que as diferenças de penas entre um e outro crime são gritantes. ${ }^{116}$

\footnotetext{
${ }^{115}$ STJ. REsp. 1327087. Rel. Min. OG Fernandes, 6 $6^{\mathrm{a}}$ turma, Destrito Federal, 10 set. 2013.

${ }^{116}$ Voto Min. Luiz Fux In: STF. HC 107.801/SP. Rel. Min. Cármen Lúcia, $1^{a}$ turma, Destrito Federal, 06 set 2011, p. 21.
} 
Não se adentra, aqui, no mérito de ser o Tribunal do Júri uma instituição boa ou ruim, mas somente na questão de se mandar à sua apreciação o que realmente se mostrar ser de sua competência. 


\section{Capítulo 6: Da banalização do dolo eventual em detrimento da culpa consciente nos casos de repercussão midiática}

Não é de hoje que se pode perceber que a sociedade brasileira, bem como outras, vem vivendo um momento de forte repúdio à criminalidade. Exigem-se punições mais severas, um basta à impunidade, redução da maioridade penal... Tudo isso muito bem fomentado pela mídia, que cada vez mais ocupa o espaço de seus programas televisivos, radiofônicos e páginas impressas ou virtuais com debates e relatos a cerca de crimes que ocorrem no dia-a-dia.

Essa sede por justiça, que muitas vezes é uma vingança disfarçada, tem causado um grave efeito colateral na aplicação do direito penal. O que se observa é uma cada dia mais frequente subversão de conceitos e teorias a fim de promover um verdadeiro "cala boca social". Uma das teorias que mais dão margem a esta subversão é justamente a teoria do dolo. Isto porque, como amplamente discutido ao longo do presente trabalho, há uma imensa dificuldade de se diferenciar no plano prático quando há dolo eventual e quando há culpa consciente. Essa linha tênue que divide ambos os institutos tem sido constantemente ultrapassada.

A fim de demonstrar mais concretamente essa problemática, debruçarnos-emos sobre dois casos concretos de imensa repercussão na atualidade.

\subsection{Atropelamento Rafael Mascarenhas}

Em um breve resumo, o primeiro e principal réu foi acusado de ter, conscientemente, e assumindo o risco do resultado lesivo, atropelado a vítima Rafael Mascarenhas, filho da atriz global Cissa Guimarães, causando-lhe a morte. Segundo a exordial acusatória, o primeiro denunciado estaria 
participando de um "racha" com o segundo denunciado, colocando em perigo a vida dos funcionários que trabalhavam na obra ao trafegar em alta velocidade por uma via interditada, via esta onde a vítima andava de skate. Além disso, teria ele avistado os skatistas no túnel e, ainda assim, continuado com sua conduta, razão pela qual teria agido com dolo eventual. Outros crimes lhes foram imputados, como corrupção ativa, evasão do local e inovação artificiosa, que por ora serão afastados da análise.

Ao longo da instrução probatória, discutiu-se a real ocorrência da disputa automobilística, tendo em vista a prova pericial (que não foi precisa ao afirmar que o carro andava acima da velocidade permitida para via) e a ausência de multas por excesso de velocidade nos pardais da região na data e hora do fato. Discutiu-se, ainda, se sabiam os réus que trafegavam por um túnel interditado, haja vista o desencontro de informações acerca do horário no qual o túnel fora fechado. Ademais, restou comprovado que o réu fez ligações para os números 190 e 193 logo após o acidente.

$\mathrm{O}$ ponto principal deste caso concreto tange a questão de estarem os réus alegadamente disputando corrida em um túnel interditado no momento do acidente. O "racha", assim como o uso de bebida alcoólica, tem sido considerado pela jurisprudência e por parte da doutrina um dos maiores indícios de dolo eventual para os homicídios cometidos no trânsito. É o que se verifica na obra de Nucci e no seguinte precedente do STF:

Tem sido posição adotada, atualmente, na jurisprudência pátria considerar a atuação do agente em determinados delitos cometidos no trânsito não mais como culpa consciente, e sim como dolo eventual. As inúmeras campanhas realizadas, demonstrando o perigo da direção perigosa e manifestamente ousada, são suficientes para esclarecer os motoristas da vedação legal de certas condutas, tais como o racha, a direção em alta velocidade, sob embriaguez, entre outras. Se, apesar disso, continua o condutor do veículo a agir dessa forma nitidamente arriscada, estará demonstrando seu desapego à incolumidade alheia, podendo responder por delito doloso. ${ }^{117}$

\footnotetext{
${ }^{117}$ NUCCI, Guilherme de Souza. Op. Cit. p. 212
} 
DIREITO PENAL E PROCESSUAL PENAL.HABEAS CORPUS. CRIME DE COMPETÊNCIA DO TRIBUNAL DO JÚRI. "RACHA" AUTOMOBILÍSTICO. HOMICÍDIO DOLOSO. DOLO EVENTUAL. NOVA VALORAÇÃO DE ELEMENTOS FÁTICO-JURÍDICOS, E NÃO REAPRECIAÇÃO DE MATERIAL PROBATÓRIO. DENEGAÇÃO. 1. A questão de direito, objeto de controvérsia neste writ, consiste na eventual análise de material fático-probatório pelo Superior Tribunal de Justiça, o que eventualmente repercutirá na configuração do dolo eventual ou da culpa consciente relacionada à conduta do paciente no evento fatal relacionado à infração de trânsito que gerou a morte dos cinco ocupantes do veículo atingido. 2. O Superior Tribunal de Justiça, ao dar provimento ao recurso especial interposto pelo Ministério Público do Estado de Minas Gerais, atribuiu nova valoração dos elementos fático-jurídicos existentes nos autos, qualificandoos como homicídio doloso, razão pela qual não procedeu ao revolvimento de material probatório para divergir da conclusão alcançada pelo Tribunal de Justiça. 3. $\mathrm{O}$ dolo eventual compreende a hipótese em que o sujeito não quer diretamente a realização do tipo penal, mas a aceita como possível ou provável (assume o risco da produção do resultado, na redação do art. 18 , I, in fine, do $\mathrm{CP}$ ). 4. Das várias teorias que buscam justificar o dolo eventual, sobressai a teoria do consentimento (ou da assunção), consoante a qual o dolo exige que o agente consinta em causar o resultado, além de considerá-lo como possível. 5.A questão central diz respeito à distinção entre dolo eventual e culpa consciente que, como se sabe, apresentam aspecto comum: a previsão do resultado ilícito. No caso concreto, a narração contida na denúncia dá conta de que o paciente e o co-réu conduziam seus respectivos veículo, realizando aquilo que coloquialmente se denominou "pega" ou "racha", em alta velocidade, em plena rodovia, atingindo um terceiro veículo (onde estavam as vítimas). 6. Para configuração do dolo eventual não é necessário o consentimento explícito do agente, nem sua consciência reflexiva em relação às circunstâncias do evento. Faz-se imprescindível que o dolo eventual se extraia das circunstâncias do evento, e não da mente do autor, eis que não se exige uma declaração expressa do agente. 7 . O dolo eventual não poderia ser descartado ou julgado inadmissível na fase do iudicium accusationis. Não houve julgamento contrário à orientação contida na Súmula 07 , do STJ, eis que apenas se procedeu à revaloração dos elementos admitidos pelo acórdão da Corte local, tratando-se de quaestio juris, e não de quaestio facti. 8. Habeas corpus denegado. $^{118}$ (grifo nosso)

Forçoso é considerar, contudo, a inexistência de uma ligação necessária entre o excesso de velocidade ou a embriaguez e o dolo eventual, posto que o agente pode agir de tal forma e, ainda assim, por mais estupidamente que seja, considerar-se apto e habilidoso o suficiente para evitar o resultado danoso. Se a sociedade clama por punição mais severa, já que os acidentes de trânsito têm crescido exponencialmente, o caminho para se atender a este rogo não é transmudando o elemento subjetivo do crime no caso concreto, mas operando

${ }^{118}$ STF. HC 91159/MG. Rel. Min. Ellen Gracie, 2a turma, Destrito Federal, 02 set 2008. 
uma mudança no ordenamento através do sistema legislativo. No dizer de

\section{Greco:}

O clamor social no sentido de que os motoristas que dirigem embriagados e/ou em velocidade excessiva devem ser punidos severamente, quando tiram a vida ou causam lesões irreversíveis em pessoas inocentes, não pode ter o condão de modificar toda a nossa estrutura jurídico-penal. Não podemos, simplesmente, condenar o motorista por dolo eventual, quando, na verdade, cometeu a infração culposamente. $^{119}$

\section{Esta problemática foi tratada com maestria por Israel Domingos Jorio:}

Séculos de desenvolvimento teórico, incontáveis horas de estudo e páginas de pesquisa parecem ter perdido sua utilidade diante de uma vontade incontrolável de criar soluções que satisfaçam um anseio pessoal ou social por 'justiça'. Justiça, nesse caso, entre aspas, eis que em uma sociedade dominada pela cultura do medo", impera a ideia de que somente se faz justiça por meio da punição. Absolvição é impunidade.

(...)

Não se pode, a pretexto de incrementar a segurança no trânsito, desconsiderar premissas que embasam o Direito Penal.

(...) impelida por um discurso midiático terrorista, a sociedade exige (contraditoriamente) respostas rápidas e eficazes entre aspas, pois aqui, a eficácia é diretamente proporcional à intensidade da punição). É essa, para os profissionais e estudiosos do Direito, a hora da decisão: manter-se fiel à técnica e usar a ciência para formar soluções sólidas e fundamentáveis ou ceder à pressão da mídia e da sociedade para apresentar respostas imediatistas que, apesar de ilusórias, contam com altos índices de adesão em função de seu (exagerado) rigor punitivo?

(...)

O segundo caminho, por sua vez, é instantâneo: basta desprezar premissas teóricas basilares para aplicar tipos penais cujas sanções sejam mais graves. É um atalho sedutor. Nada de morosos trâmites legislativos. Para penas imediatamente mais severas, só é preciso chamar de doloso aquilo que é culposo.

(...)

A partir disso, tudo é dolo eventual. Tudo importa em assumir o risco. Atualmente, parece difícil criar exemplos críveis de homicídio culposo na direção de automóvel. Beber, correr, ultrapassar, avançar sinal... Tudo isso é assumir o risco de matar. Mas só de matar? Ninguém tem medo de morrer? ${ }^{120}$

\footnotetext{
${ }^{119}$ GRECO, Rogério. Op. Cit, p. 207

${ }^{120}$ JORIO, Israel Domingos. O fetiche do dolo eventual. In: Boletim 230 IBCCRIM. São Paulo: IBCCRIM, Jan/2012. Disponível em $<$ http://www.ibccrim.org.br/boletim_artigo/4529-O-Fetiche-doDolo-eventual >
} 
No caso concreto aqui trazido, a vítima era jovem, estudante, filho de uma atriz global, e divertia-se com os amigos no momento do acidente, um conjunto de fatores que tornam a dor pela perda da vida ainda maior perante os olhos da sociedade. Entretanto, a despeito de toda a pressão midiática, foi determinada a desclassificação pelo juiz em momento oportuno, com fulcro no art. 419 do CPP, e com fundamento na inexistência de dolo eventual, posto que quem chama por socorro imediatamente após o ocorrido demonstra que o resultado danoso não the era querido e nem mesmo indiferente. Esta decisão foi recorrida com base no argumento de que não poderia o juiz afastar o dolo eventual, haja vista a existência de indícios de sua ocorrência, caso contrário estaria por usurpar a competência do Tribunal do Júri. A procuradoria de justiça deu parecer favorável à nulidade da decisão desclassificatória por excesso de linguagem e, no mérito, ao provimento do recurso. A decisão, porém, foi mantida em sede de segunda instância, entendendo a $1^{\text {a }}$ Câmara Criminal do $\mathrm{TJ} / \mathrm{RJ}$ que o princípio do in dubio pro societate somente se aplica quando há dúvida sobre a existência de animus necandi, o que não ocorreria no caso concreto, onde estaria clara a sua inexistência. A ausência de dolo eventual, ademais, foi acolhida por outro argumento: os desembargadores entenderam que não houve dolo eventual, haja vista terem os réus supostamente escolhido um local ermo, sem grande movimentação, para praticar o racha, o que denota uma preocupação com a incolumidade alheia.

As críticas, obviamente, foram imensas, com espaço aberto em programas televisivos para explanação da revolta contra a "impunidade", o que nos leva a crer que a decisão do juiz foi, no mínimo, dotada de coragem e, em nossa opinião, acertada.

Até o momento em que o processo foi acompanhado para elaboração do presente trabalho ${ }^{121}$, outra instrução corria perante o juízo singular, e ainda não havia sido prolatada sentença pelo juiz titular da vara criminal à qual o

${ }^{121}$ Processo de $\mathrm{n}^{\mathrm{o}}$ 0243823-86.2010.8.19.0001 acompanhado até Set/2014. 
processo foi destinado após a desclassificação.

\subsection{Rojão em protesto}

Duas pessoas foram denunciadas por terem, em meio a uma manifestação popular, acendido um rojão explosivo, que atingiu um cinegrafista que cobria o protesto, causando-lhe a morte. Argumenta a exordial no sentido de que ambos agiram em comunhão de ações e desígnios, e que assumiram o risco do resultado morte, visto que acenderam o artefato em meio a um aglomerado de pessoas. A imputação da inicial foi de homicídio doloso qualificado por motivo torpe (no dizer do MP, "corromper a legitimidade de uma manifestação popular") e meio que impossibilitou a defesa da vítima (o rojão a atingiu pelas costas), combinado com o crime de explosão.

Um detalhe a ser ressaltado é o requerimento de prisão temporária dos acusados feito pela autoridade policial, com parecer favorável do Ministério Público e decretação estabelecida pelo magistrado, tendo como argumento o fato de que "o delito foi grave e de intensa repulsa social, devendo ser severamente reprimido pelo Estado, garantindo-se a ordem pública com a prisão". No contexto, um dos acusados havia se apresentado espontaneamente na delegacia para prestar depoimento, era réu primário, de bons antecedentes, estudante com residência fixa. Mais uma vez deparamo-nos com ações dos operadores do direito embasadas por uma necessidade de "mostrar serviço" à sociedade. A prisão temporária foi posteriormente convertida em preventiva, tendo sido impetrado Habeas Corpus sem êxito pela defesa.

Passada a instrução, nas alegações finais ministeriais, a conjugação do homicídio com o crime de explosão foi substituída pela qualificadora de uso de material explosivo, tendo sido pedida a pronúncia por homicídio qualificado por meio que impossibilitou a vítima, uso de explosivo e motivo torpe. O MP reafirmou que os acusados agiram em comunhão de desígnios, 
tendo previamente acordado sobre a prática do delito. Ademais, alegou que tinham eles o domínio funcional do fato e que, no que tange ao elemento anímico, não seria o momento oportuno para analisá-lo, já que isto caberia à corte de sentença. Os indícios necessários para a pronúncia já se fariam presentes.

A defesa de um dos réus alegou nulidade do processo por insuficiência da defesa técnica que o patrocinara no início do processo, entre outras preliminares. No mérito, ambas alegaram a ausência de dolo eventual, dado que não houve qualquer indício da existência do mesmo. O que houve, sim, foi uma conduta destinada a desestabilizar a força policial desprovida de cuidado que acabou por gerar o resultado danoso, mas isto enseja a existência de culpa consciente e não dolo eventual. Ademais, se houvesse no caso dolo eventual de matar, teria também dolo de suicídio, visto que no momento da explosão os réus encontravam-se mais próximos do explosivo do que a própria vítima.

Nilo Batista, em publicação recente sobre este caso concreto, afirmou categoricamente:

Suprimir as fronteiras entre o dolo eventual e a culpa temerária é um dos dispositivos mais recorrentes no ativismo punitivista. De modo geral, no noticiáriopolicial e na crônica forense, o 'assumir o risco de produzir o resultado' (art. 18, inc. I, CP) é interpretado como 'correr o risco' (no que o dolo eventual não se diferenciaria em nada da culpa temerária) ... Na verdade, a insustentável opção teórica pelo dolo eventual frequentemente está encobrindo uma opção ideológica pela pena mais grave, ainda que o delito tenha sido mais leve.

(...).

..o objetivo do manifestante era que o rojão se deslocasse na direção dos policiais militares, não só protegidos por escudos como adestrados para proteger-se, tal como acontecera em tantos conflitos no país: a PM, atrás de seus escudos, disparando armas de fogo municiadas com balas de chumbo ou de borracha e também de gás lacrimogéneo ou de efeito moral, e os manifestantes, atrás de suas máscaras, disparando rojões e mais raramente coquetéis molotov. ${ }^{122}$

O mencionado jurista ressalta ainda que os réus sequer possuíam

\footnotetext{
${ }^{122}$ BATISTA, Nilo. As duas faces do domínio do fato. Rio de Janeiro: 2014. Disponível em < http://cleciolemos.blogspot.com.br/2014/02/nilo-batista-as-duas-faces-do-dominio.html >
} 
domínio sobre o curso causal, haja vista que o rojão depois de acesso dispara em direção indeterminada, domínio este essencial quando se fala em crime doloso. Mais um motivo para que não se considere o homicídio do jornalista doloso, ainda que por eventualidade.

Mais uma vez estamos diante de um caso de pressão midiática, inflada especificamente por ter sido a vítima um profissional da imprensa. E também de pressão política, haja vista a necessidade de contenção das crescentes manifestações populares. Ambas exigindo uma resposta severamente eficiente, o que influencia de forma grave na aplicação da teoria do dolo. Os meios de comunicação não exitaram em classificar os réus como os temidos "Black Blocks" e afetaram de forma direta o processo penal, por exemplo colhendo confissão dos reús em entrevista à TV aberta de âmbito nacional.

Diversamente do que ocorreu no caso trazido à baila anteriormente, neste, a decisão do magistrado foi pela pronúncia dos réus nos moldes do pleito ministerial (homicídio triplamente qualificado). O fundamento foi no sentido de que o procedimento no Tribunal do Júri se divide em dois momentos: judicium acusationis e judicium causae. O momento da decisão do magistrado ao final da instrução seria tão somente sobre a admissibilidade da acusação e esta é admissível quando há fundada suspeita e não quando há certeza; e a incerteza deve ser a favor da sociedade (in dubio pro societate). Tudo isto porque não se poderia tirar dos jurados a sua competência constitucionalmente estabelecida.

Houve recurso defensivo que ainda não havia sido julgado até o momento da conclusão do presente trabalho. ${ }^{123}$

${ }^{123}$ Processo de $\mathrm{n}^{\mathrm{o}}$ 0045813-57.2014.8.19.0001 acompanhado até Set/2014. 


\section{Conclusão}

O cenário no qual o Direito Penal é empregado na atualidade, sem dúvidas, é marcado pelo medo e pela insegurança da população, dada a crescente ocorrência de crimes que chocam a sociedade como um todo. Esses sentimentos fazem nascer uma sede por justiça. No tocante a isso, a despeito de se encontrar na doutrina aqueles que entendem ser a justiça o objetivo que o direito pretende realizar, o conceito de justiça é extremamente subjetivo, podendo ser alcançado por mais de dez caminhos distintos, alguns deles, inclusive, contrários à aplicação da lei - quando esta é considerada injusta. Existem aqueles que pensam ser a justiça a junção de valores fundamentais atemporais que estão presentes em toda a sociedade (justiça absoluta); aqueles que entendem ser os valores aceitos pela maioria dos membros da sociedade (histoicismo); aqueles que acreditam ser impossível se chegar a um conceito único de justiça, posto que cada indivíduo tem o seu (relativismo de Kelsen); aqueles que pensam ser "dar a cada um o que é seu" ou simplesmente aplicar a lei de forma estreita, e etc. ${ }^{124}$ Fato é que muitas vezes deparamo-nos com situações em que clama-se por uma justiça que mais se assemelha à vingança e, definitivamente, o papel do Direito Penal não é vingar, já passamos há muito dos tempos de Talião. ${ }^{125}$

Entretanto, o problema maior não está propriamente em se querer uma vingança. Pode-se dizer, até, que este é um desejo inerente ao ser humano. A questão se torna crítica quando este desejo passa a influenciar na aplicação do direito, já que esta deve ser imparcial. E se tiver de pender para um dos lados, deve ser para o lado do réu, segundo aplicação do princípio basilar da presunção de inocência, explicitado em capítulo anterior. A influência ocorre, sobretudo, nas omissões e tenuidades da lei e da teoria penal. Como foi

\footnotetext{
${ }^{124}$ DIMOULIS, Dimitri. Manual de introdução ao estudo do direito. $2^{\mathrm{a}}$ ed., rev. atual. e ampl. São Paulo: Editora Revistra dos Tribunais, 2008. p. 132 e segts.

125 "Olho por olho, dente por dente"
} 
largamente demonstrado, a teoria do dolo é um desses objetos facilmente passíveis de subversão. E a ânsia de se jogar para o alto as regras e princípios a fim de se alcançar o objetivo implacavelmente pretendido é fomentado por discursos punitivistas propagados incessantemente pelos meios de comunicação. Criou-se uma verdadeira criminologia midiática. O acusado entra no processo já condenado.

Simone Schreiber, desembargadora federal, escreveu sua tese de doutorado sobre o fenômeno da publicidade nos processos criminais. Em um brilhante parecer escrito por ela sobre o mesmo tema ao IAB, ressaltou 3 sinais que identificam haver um embate entre a liberdade de expressão e o direito a um julgamento justo e imparcial e demonstram a necessidade de se buscar uma medida restritiva. ${ }^{126} \mathrm{O}$ primeiro deles é o caráter prejudicial das manifestações da mídia que se caracteriza quando as notícias são opinativas, sustentando a existência de culpa. Exemplos são as interceptações telefônicas ilegais e gravações sem conhecimento do acusado. É muito comum que os programas façam reportagens nas quais o jornalista se passa por alguma figura e atua de modo a gerar um "flagrante". É também comum programas que se dedicam quase que inteiramente a minuciar crimes ocorridos no dia-a-dia e tem como âncoras verdadeiros "defensores da sociedade". Não raro deparamonos com verdadeiros discursos de ódio como o feito pela jornalista Rachel Sheherazade, que rendeu uma ação civil pública contra a emissora que o veiculou, no episódio dos "justiceiros do Flamengo", no qual um grupo de pessoas amarrou um menor infrator nu no poste e o espancou. A mencionada jornalista incitou, em horário nobre de um canal aberto, a população a promover a vingança pelas próprias mãos, afirmando tratar-se de legítima defesa coletiva e terminou aconselhando que aqueles que fossem defensores

\footnotetext{
${ }^{126}$ SCHREIBER, Simone. Parecer no 040/2008 destinado ao IAB de 04 fev 2009. Disponível em < http://www.iabnacional.org.br/IMG/pdf/doc-1505.pdf >. Acesso em 29 out 2014.
} 
dos direitos humanos poderiam iniciar a campanha "adote um bandido". ${ }^{127}$

O segundo elemento citado por Schreiber é o risco potencial de que as reportagens influenciem no processo. Neste ponto, a autora cita precedentes internacionais nos quais considerou-se nulo um processo dada a intensidade do empenho midiático em denegrir a imagem do réu. $\mathrm{O}$ terceiro e último elemento é que o julgamento seja atual, ou seja, que esteja ocorrendo algum dos atos entre inquérito e o sentença definitiva. Para Shreiber, é preciso haver uma ponderação entre os direitos constitucionais à liberdade de expressão e ao julgamento imparcial através da proporcionalidade, de modo a se buscar um processo justo tentando restringir minimamente o direito à livre expressão e tendo sempre em vista se o grau da restrição se justifica pela importância do que se procura proteger. Entre as medidas a serem possivelmente adotadas para resolver o problema, cita a autora: postergação do julgamento, vedação do uso de provas produzidas pela mídia, restrição à publicidade do julgamento, criminalização da publicidade opressiva, entre outras.

É preciso esclarecer que de forma alguma aqui se pretende defender qualquer tipo de censura. $\mathrm{O}$ que se visa criticar é a afetação da atuação dos juristas promovida por esses discursos. É necessário que, sobretudo aqueles que estudaram o Direito e hoje estão investidos em funções importantes à sua aplicação, não se deixem influenciar por fatores externos dessa forma. Eugênio Zaffaroni, inclusive, em palestra ${ }^{128}$ recente nas dependências da Pontifícia Universidade Católica do Rio de Janeiro, afirmou que no atual momento brasileiro uma forma de se evitar tamanha comoção seria revestir os magistrados de maiores garantias, para que se sentissem seguros de decidir segundo o direito e não segundo o clamor social.

Aury Lopes Jr, ressalta, ainda, que a contenção dos excessos na apreciação da mídia é verdadeira aplicação do princípio constitucional da

\footnotetext{
${ }^{127}$ Rachel Sheherazade no telejornal SBT Brasil veiculado na televisão em 04 fev 2014. Disponível em $<$ https://www.youtube.com/watch?v=unVIpQHLDwE > . Acessado em 02 out. 2014.

${ }^{128}$ Palestra ministrada em 02 set 2014 no auditório B6 da PUC-Rio
} 
presunção de inocência.

...a presunção de inocência, enquanto princípio reitor do processo penal, deve ser maximizada em todas suas nuances, mas especialmente no que se refere à carga da prova (regla del juicio) e às regras de tratamento do imputado (limites à publicidade abusive [estigmatização do imputado] e à limitação do (ab)uso das prisões cautelares).

(...)

... a presunção de inocência (e também as garantias constitucionais da imagem, dignidade e privacidade) deve ser utilizada como verdadeiros limites democráticos à abusiva exploração midiática em torno do fato criminoso e do próprio processo judicial. O bizarro espetáculo montado pelo julgamento midiático deve ser coibido pela eficácia da presunção de inocência. ${ }^{129}$

Ou seja, a presunção de inocência, mais do que um aspecto interno tangente ao campo da prova e do julgamento pelo juíz, possui também um aspecto externo, que remete à questão de se dever evitar que o réu seja prematuramente condenado pela opinião pública.

A problemática da subversão da teoria do dolo, bem como da influência da mídia nos julgamentos criminais, ainda não foi suficientemente debatida, tampouco ganhou a visibilidade necessária. Embora haja inúmeras manifestações críticas de importantes doutrinadores acerca do tema, as decisões subversivas continuam a se multiplicar, algo cujo desfecho pode se mostrar tão ou mais perigoso que a criminalidade que a sociedade visa exterminar.

${ }^{129}$ LOPES JR, Aury. Op. Cit. p. 188 


\section{REFERÊNCIAS BIBLIOGRÁFICAS}

JESUS, Damásio de. Direito penal: volume 1: parte geral. $32^{a}$ ed. São Paulo: Saraiva, 2011.

ZAFFARONI, Eugenio Raúl; PIERANGELI, José Henrique. Manual de Direito Penal Brasileiro: Vol 1 - Parte Geral. 9 $9^{\text {a }}$ ed. Rev. E atual. São Paulo: Revista dos Tribunais, 2011.

BITTENCOURT, Cezar Roberto. Tratado de Direito Penal: parte geral. $16^{\mathrm{a}}$ ed. São Paulo: Saraiva, 2011.

BITENCOURT, Cezar Roberto. Tratado de Direito Penal: parte especial dos crimes contra a pessoa. $13^{\mathrm{a}}$ ed. rev., ampl. e atual. de acordo com as Leis n. 12.653, 12.720 e 12.737, de 2012. São Paulo: Saraiva, 2013.

GRECO, Rogério. Curso de Direito Penal. $13^{\mathrm{a}}$ ed. Rio de Janeiro: Impetus, 2011.

PRADO, Luiz Regis. Curso de direito penal brasileiro: parte geral: arts. $1^{\circ}$ a 120. $8^{\text {a }}$ ed. rev., atual. e ampl. São Paulo: Revista dos Tribunais, 2008.

MIRABETE, Julio Fabbrini; FABBRINI, Renato N. Manual de direito penal: volume 1: parte geral, arts $1^{\circ}$ a 120 do CP. $27^{\mathrm{a}}$ ed. rev. $\mathrm{r}$ atual. até 4 de janeiro de 2011. São Paulo: Atlas, 2011.

COSTA JR, Paulo José da. Curso de direito penal. $10^{\text {a }}$ ed. rev. e atual. São Paulo: Saraiva, 2009. 
WELZEL, Hans. Derecho Penal: parte general. Traduzido por Carlos Fontán Balestra. Buenos Aires: Roque Depalma Editor, 1956.

ROXIN, Claus. Derecho penal: parte general, tomo I: fundamentos, la estructura de la teoria del delito. Trad por PEÑA, Diego-Manuel Luzón, CONLLEDO, Miguel Díaz y García, e ROMESAL, Javier de Vicente. $1^{\text {a }}$ ed. Madrid: Civitas, 1997.

FRAGOSO, Heleno Cláudio. Lições de direito penal: parte geral. $16^{\mathrm{a}}$ ed. rev. por Fernando Fragoso. Rio de Janeiro: Forense, 2004.

BITENCOURT, Cezar Roberto. Código penal comentado. $5^{\mathrm{a}}$ ed. atual. São Paulo: Saraiva, 2009.

LOPES JR, Aury. Direito processual penal e sua conformidade constitucional. Volume I, 7ª ed. Rio de Janeiro: Lumen Juris, 2011.

OLIVEIRA, Eugênio Pacelli de. Curso de processo penal. $16^{\mathrm{a}}$ ed. atual. de acordo com as Leis n. 12.403, 12.432, 12.461, 12.483 e 12.529, todas de 2011, e Lei Complementar n. 140 de 8 de dezembro de 2011. São Paulo: Atlas, 2012.

NUCCI, Guilherme de Souza. Código Penal Comentado. $11^{\mathrm{a}}$ ed. rev., atual. e ampl. São Paulo: Revista dos Tribunais, 2012.

TOURINHO FILHO, Fernando da Costa. Processo penal, volume I. $34^{\mathrm{a}}$ ed. rev. e de acordo com a Lei n 12403/2011. São Paulo: Saraiva, 2012. 
DIMOULIS, Dimitri. Manual de introdução ao estudo do direito. $2^{\mathrm{a}}$ ed., rev. atual. e ampl. São Paulo: Editora Revistra dos Tribunais, 2008.

CAPEZ, Fernando. Curso de processo penal. $16^{\mathrm{a}}$ ed. São Paulo: Saraiva, 2009.

TAVARES, Juarez. Espécies de dolo e outros elementos subjetivos do tipo. Revista de Direito Penal. Disponível em $<$ http://ojs.c3sl.ufpr.br/ojs/index.php/direito/article/view/7199/5150> Acesso em 13 ago. 2014.

CONCEIÇÃO, Arnaldo Alves da. Distinção de dolo eventual e culpa consciente. In: Âmbito Jurídico, Rio Grande, XIII, n. 79, ago 2010. Acesso em 10 set 2014.

PEREIRA, Juarez Maynart; PEREIRA, Dora Maynart. O principio constitucional da presunção de inocência, o in dubio pro reo e a aplicação do in dubio pro societate na decisão de pronúncia. In: Âmbito Jurídico, Rio Grande, XVI, n. 116, set 2013. Disponível em <http://ambitojuridico.com.br/site/?n_link=revista_artigos_leitura\&artigo_id=13622\&revista _caderno=22.> Acesso em 12 set. 2014.

JORIO, Israel Domingos. O fetiche do dolo eventual. In: Boletim 230 IBCCRIM. São Paulo: IBCCRIM, Jan/2012. Disponível em $<$ http://www.ibccrim.org.br/boletim_artigo/4529-O-Fetiche-do-Doloeventual> Acesso em 17 set. 2014.

BATISTA, Nilo. As duas faces do domínio do fato. Rio de Janeiro: 2014. Disponível em <http://cleciolemos.blogspot.com.br/2014/02/nilo-batista-as- 
duas-faces-do-dominio.html> Acesso em 10 out. 2014.

TJ/RJ. RESE. Processo $n^{0}$ 0107990-62.2011.8.19.0001, Rel. Des. Monica Tolledo de Oliveira, Rio de Janeiro, 03 dez. 2013.

STF. RHC 116950. Rel. Min. Rosa Weber, $1^{\text {a }}$ turma, Destrito Federal, 03 dez 2013.

STJ. REsp. 1327087. Rel. Min. OG Fernandes, $6^{\mathrm{a}}$ turma, Destrito Federal, 10 set. 2013.

STF. HC 107.801/SP. Rel. Min. Cármen Lúcia, 1ª turma, Destrito Federal, 06 set 2011 .

STF. HC 91159/MG. Rel. Min. Ellen Gracie, $2^{\mathrm{a}}$ turma, Destrito Federal, 02 set 2008 .

SCHREIBER, Simone. Parecer n ${ }^{\circ}$ 040/2008 destinado ao IAB de 04 fev 2009. Disponível em < http://www.iabnacional.org.br/IMG/pdf/doc-1505.pdf >. Acesso em 29 out 2014.

Declaração de Direitos do Homem e do Cidadão de 1789. Disponível em < http://www.legifrance.gouv.fr/Droit-francais/Constitution/Declaration-desDroits-de-1-Homme-et-du-Citoyen-de-1789 >. Acesso em 12 out. 2014.

Reportagem SBT Brasil veiculada na televisão em 04 fev 2014. Disponível em $<$ https://www.youtube.com/watch?v=unVIpQHLDwE >. Acesso em 02 out. 2014. 